Short title: Multiplex serosurveillance in coastal Kenya

\title{
Multiplex serologic testing within a cross-sectional lymphatic filariasis sentinel site survey in coastal Kenya reveals community-level differences in IgG antibody responses to parasitic diseases and vaccines.
}

Sammy M. Njenga ${ }^{1 *}$, Henry M. Kanyi ${ }^{1}$, Benjamin F. Arnold ${ }^{2}$, Hadley S. Matendechero ${ }^{3}$, Joyce K. Onsongo ${ }^{4}$, Kimberly Y. Won ${ }^{5,6,7}$, Jeffrey W. Priest ${ }^{5}$

${ }^{1}$ Eastern and Southern Africa Centre of International Parasite Control, Kenya Medical Research Institute, Kenya

${ }^{2}$ Division of Epidemiology and Biostatistics, University of California, Berkeley, USA

${ }^{3}$ Neglected Tropical Diseases Unit, Department of Preventive and Promotive Services, Ministry of Health, Kenya

${ }^{4}$ WHO-AFRO Country office, Kenya

${ }^{5}$ Centers for Disease Control and Prevention, United States of America

${ }^{6}$ Swiss Tropical and Public Health Institute, Basel, Switzerland

${ }^{7}$ University of Basel, Basel, Switzerland

* Corresponding author

E-mail: sammynjenga@gmail.com 
bioRxiv preprint doi: https://doi.org/10.1101/604181; this version posted April 19, 2019. The copyright holder for this preprint (which was

not certified by peer review) is the author/funder, who has granted bioRxiv a license to display the preprint in perpetuity. It is made available under aCC-BY 4.0 International license.

Short title: Multiplex serosurveillance in coastal Kenya

\section{Abstract}

Accurate, cost-effective measurement of the burden of co-endemic infections would enable public health managers to identify opportunities for implementation of integrated control programs. Dried blood spots (DBS) collected during a cross-sectional lymphatic filariasis sentinel site survey in the Kenyan coastal counties of Lamu, Tana River, Kilifi, Kwale, and Taita-Taveta were used for the integrated detection of serologic IgG antibodies against antigens from several parasitic infections (Wuchereria bancrofti, Schistosoma mansoni, Plasmodium spp, Ascaris lumbricoides, and Strongyloides stercoralis) as well as markers for immunity to vaccine-preventable diseases (measles, diphtheria, and tetanus) on a multiplex bead assay (MBA) platform. High heterogeneity was observed in antibody responses by pathogen and antigen across the sentinel sites. Antibody seroprevalence against $\mathrm{Wb} 123, \mathrm{Bm} 14$, and $\mathrm{Bm} 33$ recombinant filarial antigens were generally higher in Ndau Island ( $p<0.0001)$, which also had the highest prevalence of filarial antigenemia compared to other communities. Antibody responses to the Plasmodium species antigens CSP and MSP-1 $1_{19}$ were higher in Kilifi and Kwale counties, with Jaribuni community showing higher overall mean seroprevalence $(p<0.0001)$. Kimorigo community in Taita-Taveta County was the only area where antibody responses against Schistosoma mansoni Sm25 recombinant antigen were detected. Seroprevalence rates to Strongyloides antigen NIE ranged between $3 \%$ and $26 \%$, and there was high heterogeneity in immune responses against an Ascaris antigen among the study communities. Differences were observed between communities in terms of seroprevalence to vaccine-preventable diseases. Seroprotection to tetanus was lower in all 3 communities in Kwale County compared to the rest of the communities. This study has demonstrated that the MBA platform holds promise for rapid integrated monitoring of trends of infections of public health importance in endemic areas, and assessing the effectiveness of control and elimination programs. 
Short title: Multiplex serosurveillance in coastal Kenya

\section{Author Summary}

Establishment of successful private-public partnerships in the recent past has led to an increase in resources available for control and elimination of malaria and Neglected Tropical Diseases (NTDs). Implementation of control and elimination programs and their subsequent monitoring and evaluation would be greatly facilitated by development of new tools and strategies for rapid identification of areas of transmission so that interventions could be prioritized to regions where they were most needed. Since development of antibody responses in a host depend on exposure to an infectious agent, assessment of such serologic markers provides a sensitive way to measure differences between populations in pathogen exposure. Our study applied a state-of-theart multiplex bead assay platform to perform integrated measurement of antibody responses to multiple parasitic diseases and immunizing antigens for vaccine-preventable diseases (VPDs) in ten lymphatic filariasis sentinel sites across the Kenyan coastal region. A community-level analysis of age-specific and overall mean seroprevalence fit using a flexible model ensemble provided an improved understanding about the distributions of the various parasitic infections and seroprotection to VPDs. This study provides an important proof of concept for how we could dramatically increase the value of existing surveillance activities using small volumes of blood collected on filter paper and analyzed using a single multiplex laboratory assay and novel data analysis techniques. 
Short title: Multiplex serosurveillance in coastal Kenya

\section{Introduction}

Persons living in tropical and subtropical areas are often faced with enormous health challenges resulting from the co-endemicity of HIV/AIDS, tuberculosis, and malaria. In addition, several other infectious diseases found in sub-Saharan Africa including some Neglected Tropical Diseases (NTDs) are common, particularly among the poor [1-3]. Past studies in the region have identified subgroups who are polyparasitized with soil-transmitted helminth (STH) infections, filarial parasites, and malaria [4-6]. Lymphatic filariasis (LF) caused by Wuchereria bancrofti is principally confined to the coastal region of Kenya where ecological factors are suitable for its transmission [7]; the disease co-occurs with other infectious diseases such as STH infections, schistosomiasis, lower respiratory infections, and malaria [8-10].

In the past, lack of resources and competing health priorities in sub-Saharan Africa have led to insufficient commitments to control NTDs. More recently, implementation of successful publicprivate partnerships (PPPs) for health have availed resources for control and/or elimination of NTDs as public health problems. In 2000 the World Health Organization (WHO) Global Programme to Eliminate Lymphatic Filariasis (GPELF), launched in response to World Health Assembly resolution WHA50.29, urged Member States to initiate activities to eliminate LF as a public health problem, a goal subsequently targeted for 2020 [11]. Community-wide mass drug administration (MDA) of antifilarial drugs for 4-6 years is recommended for LF elimination, and modeling studies have estimated adequate treatment coverage to be at least $65 \%$ of total population in endemic areas $[12,13]$. Substantial progress has been made towards elimination of LF, with Togo being the first country in sub-Saharan Africa to be recognized by WHO for eliminating the disease as a public health problem $[14,15]$. The Kenyan Ministry of Health launched an LF elimination program in 2002, but the program did not sustain MDA campaigns annually as per GPELF recommendations [16,17]. In 2015, the Ministry of Health successfully appealed to World Health Organization Regional Office for Africa (WHO-AFRO) and other partners for support to re-establish annual MDA campaigns. Subsequently, 
bioRxiv preprint doi: https://doi.org/10.1101/604181; this version posted April 19, 2019. The copyright holder for this preprint (which was

not certified by peer review) is the author/funder, who has granted bioRxiv a license to display the preprint in perpetuity. It is made available under aCC-BY 4.0 International license.

Short title: Multiplex serosurveillance in coastal Kenya

the WHO Country Office selected the Eastern and Southern Africa Centre of International Parasitic Control (ESACIPAC), which is part of the Kenya Medical Research Institute (KEMRI), to conduct a comprehensive epidemiological assessment of LF infection before re-starting MDA.

Antibody levels can provide valuable information about exposure to infections and can be helpful for characterizing pathogen transmission dynamics to help identify where interventions are needed the most. As some parasite antigens are known to elicit an immunoglobulin $G$ (IgG) response that can be detected for a long period of time, serological analysis of young children provide an estimate of more recent exposure $[18,19]$. A state-of-art multiplex bead assay (MBA) serological platform that enables simultaneous detection of antibodies against multiple antigens using a small volume of blood sample dried on filter paper [10 $\mu \mathrm{L}$ dried blood spots (DBS)] has been developed as a tool for integrated biomarker surveys [20-22]. The MBA has successfully been used to simultaneously measure antibody responses to multiple parasitic diseases of public health importance as part of a vaccine-preventable disease serological survey in Cambodia [23]. The platform has also been used to simultaneously assess $\lg G$ responses to a panel of malaria antigens $[24,25]$. In the current study, the MBA platform was used for multiplex serosurveillance of diseases of public health importance by testing for antibodies against LF and several other parasitic diseases (malaria, schistosomiasis, ascariasis, strongyloidiasis) as well as seroprevalence to selected vaccinepreventable diseases (measles, diphtheria, and tetanus).

\section{Methods}

\section{Study design and samples}

The DBS samples used in this study were collected during a cross-sectional LF survey conducted in October 2015 in ten sentinel sites located across the coastal region in Taita-Taveta, Kwale, Kilifi, Tana River and Lamu counties as previously described [17]. Briefly, 300 persons aged 2 years or more in each sentinel site were targeted for the LF survey as recommended in the WHO guidelines [11]. The characteristics of the study participants are described in Njenga et al. [17]. The 
bioRxiv preprint doi: https://doi.org/10.1101/604181; this version posted April 19, 2019. The copyright holder for this preprint (which was

not certified by peer review) is the author/funder, who has granted bioRxiv a license to display the preprint in perpetuity. It is made available under aCC-BY 4.0 International license.

Short title: Multiplex serosurveillance in coastal Kenya

middle finger of consenting individuals was cleaned using a cotton ball soaked in $70 \%$ isopropyl alcohol. After drying, the tip of the finger was pricked using a sterile lancet and blood was collected into capillary tubes for detection of circulating filarial antigen (CFA) by immunochromatographic card test (ICT) and onto filter paper for preparation of dried blood spots ( 6 spots of $10 \mu$ l each; Tropbio Pty Ltd, Queensland, Australia) which were used for the MBA.

\section{Ethical considerations}

The study received ethical approval from Kenya Medical Research Institute (KEMRI) Scientific and Ethics Review Unit (SSC No. 3018). In the study villages, chiefs and assistant chiefs arranged for community mobilization meetings during which the purpose of the survey and procedures to be followed were explained. Written informed consent was obtained from every individual who agreed to participate in this study; parents or legal guardians provided signed informed consent forms on behalf of children under 18 years of age. All of the community acquired samples were assayed in the KEMRI-ESACIPAC laboratory in Nairobi, Kenya.

\section{Recombinant antigens and coupling to microsphere beads}

Recombinant Schistosoma mansoni glutathione-S-transferase (GST) protein was expressed from pGEX 4T-2 plasmid (GE Healthcare, Piscataway, NJ) and purified as previously described [26]. GST fusion proteins that included protein sequences from Brugia malayi [Bm33; [21] and Bm14; [19]], Strongyloides stercoralis [NIE; [27]], and Plasmodium falciparum 3D7 strain [MSP1 ${ }_{19}$; [28]] were expressed and purified as previously described. A W. bancrofti Wb123-GST fusion protein was a kind gift from T. Nutman (NIH, Bethesda, MD). These proteins were coupled to SeroMap beads (Luminex Corp., Austin TX) using the protein quantities and buffer conditions previously described [23]. S. mansoni native soluble egg antigen (SEA) was a kind gift of E. Secor (CDC, Atlanta, GA), and recombinant S. mansoni Sm 25 antigen was expressed using the Baculovirus system previously described [29]. Both proteins were coupled to SeroMap beads using the protein quantities and buffer conditions previously described [29]. 
bioRxiv preprint doi: https://doi.org/10.1101/604181; this version posted April 19, 2019. The copyright holder for this preprint (which was

not certified by peer review) is the author/funder, who has granted bioRxiv a license to display the preprint in perpetuity. It is made available under aCC-BY 4.0 International license.

Short title: Multiplex serosurveillance in coastal Kenya

Tetanus toxoid (Massachusetts Biological Laboratories, Boston, MA), diphtheria toxoid from Corynebacterium diphtheriae (List Biological Laboratories, Campbell, CA), and recombinant measles nucleoprotein (MV-N, Meridian Life Sciences, Memphis, TN) [30] were purchased from commercial sources. Tetanus toxoid was coupled to SeroMap beads as previously described [31]. Diphtheria toxoid was coupled in buffer containing $50 \mathrm{mM}$ 2-(N-morpholinoethanesulfonic acid (MES) at pH 5.0 with $0.85 \% \mathrm{NaCl}$ at a concentration of $60 \mu \mathrm{g}$ of protein per $1.25 \times 10^{7}$ beads in $1 \mathrm{ml}$ final volume. In order to decrease background reactivity, measles MV-N was purified by chromatography on a MonoQ HR 5/5 strong anion exchange column (GE Healthcare, Piscataway, NJ) prior to use. Protein $(0.75 \mathrm{mg}$ ) was loaded onto the column at a flow rate of $1 \mathrm{ml} / \mathrm{min}$ and washed with $4 \mathrm{ml}$ of $25 \mathrm{mM}$ Tris buffer at $\mathrm{pH}$ 8.0. This was followed by a $10 \mathrm{ml}$ linear gradient to $0.25 \mathrm{M} \mathrm{NaCl}$ in Tris buffer, then by a $5 \mathrm{ml}$ linear gradient to $1 \mathrm{M} \mathrm{NaCl}$ in Tris buffer. The majority of antibody-reactive MV-N eluted in the high salt fractions between 0.4 and $0.7 \mathrm{M} \mathrm{NaCl}$. These fractions were pooled, concentrated using a Centricon-30 centifugal filter device (Millipore Corporation, Bedford, MA), and exchanged into buffer containing $10 \mathrm{mM}$ sodium phosphate with $0.85 \% \mathrm{NaCl}$ at pH 7.2 (PBS). Approximately $115 \mu \mathrm{g}$ of protein was recovered (BCA micro assay, Pierce, Rockford, IL). MonoQ purified MV-N was coupled in buffer containing $50 \mathrm{mM}$ MES at pH 5.0 with $0.85 \% \mathrm{NaCl}$ at a concentration of $6 \mu \mathrm{g}$ of protein per $1.25 \times 10^{7}$ beads in $1 \mathrm{ml}$ final volume.

Purified native hemoglobin $(\mathrm{Hb})$ from Ascaris suum worms was a kind gift from P. Geldhof (Ghent University, Belgium) [32,33]. This antigen was coupled to $1.25 \times 10^{7}$ SeroMap beads in PBS buffer $(\mathrm{pH} 7.2)$ at a concentration of $120 \mu \mathrm{g} / \mathrm{ml}$.

Cloning of the P. malariae $\mathrm{MSP}_{19}$ coding sequence from China I parasite strain is described elsewhere (Priest et al., in preparation). This antigen was coupled to $1.25 \times 10^{7}$ SeroMap beads in $50 \mathrm{mM}$ MES buffer at pH 5.0 with $0.85 \% \mathrm{NaCl}$ at a concentration of $30 \mu \mathrm{g} / \mathrm{ml}$. The glutaraldehyde protocol of Benitez et al. [34] was used to cross-link a synthetic 20 amino acid peptide [(NANP) $)^{-}$ amide] corresponding to the carboxy-terminal repeat of the $P$. falciparum circumsporozoite protein 
bioRxiv preprint doi: https://doi.org/10.1101/604181; this version posted April 19, 2019. The copyright holder for this preprint (which was

not certified by peer review) is the author/funder, who has granted bioRxiv a license to display the preprint in perpetuity. It is made available under aCC-BY 4.0 International license.

Short title: Multiplex serosurveillance in coastal Kenya

(PfCSP) $[35,36]$ to purified GST protein. Bead coupling conditions for this antigen were identical to those described above for the P. malariae $\mathrm{MSP}_{19}$ protein.

\section{Multiplex bead assay}

One bloodspot from each person, corresponding to about $10 \mu$ of whole blood, was eluted overnight at $4^{\circ} \mathrm{C}$ with 200 microliters of PBS containing $0.05 \%$ Tween-20 and $0.05 \%$ sodium azide (1:40 serum dilution assuming a $50 \%$ hematocrit). A further dilution of 50 microliters of eluate into $450 \mu$ l of PBS containing $0.5 \%$ casein, $0.3 \%$ Tween $20,0.02 \%$ sodium azide, $0.5 \%$ polyvinyl alcohol (PVA), and $0.8 \%$ polyvinylpyrrolidone (PVP) (designated as PBN1) with 3 micrograms $/ \mathrm{ml}$ Escherichia coli extract was made for a final serum dilution of 1:400. Serum dilutions were centrifuged at maximum speed to pellet the $E$. coli extract particulates immediately before use. Bloodspot dilutions were assayed in duplicate with antigen-coupled microsphere beads using a BioPlex 200 system platform (Bio-Rad, Hercules, CA) as previously described $[21,23,25]$. The average of the median fluorescent intensity values from the duplicate wells minus the background fluorescence from the buffer-only blank was reported as the "median fluorescence intensity minus background" (MFI-bg). Samples having a coefficient of variation of $>15 \%$ for $\geq 2$ positive responses between the duplicate wells were repeated.

\section{Cutoff determinations}

WHO International Standard reference sera for tetanus (TE-3; $120 \mathrm{IU} / \mathrm{ml}$ ) and diphtheria (10/262; $2 \mathrm{IU} / \mathrm{ml})$ purchased from the National Institute for Biological Standards and Control (NIBSC) (Potters Bar, Hertfordshire, United Kingdom) were used to identify MFI-bg cutoff values corresponding to immunoprotection. A tetanus TE-3 value of $10 \mathrm{mIU} / \mathrm{ml}[37,38]$ corresponded to a tetanus toxoid MBA response of $118 \mathrm{MFI}-\mathrm{bg}$ units. A diphtheria toxoid MBA response of $4393 \mathrm{MFI}-$ bg units corresponded to the $0.1 \mathrm{IU} / \mathrm{ml}$ threshold for complete protection [39], and an MBA response of $183 \mathrm{MFI}-\mathrm{bg}$ units corresponded to the $0.01 \mathrm{IU} / \mathrm{ml}$ threshold for partial protection. Others have shown good concordance between the 'gold standard' assays for tetanus and 
bioRxiv preprint doi: https://doi.org/10.1101/604181; this version posted April 19, 2019. The copyright holder for this preprint (which was

not certified by peer review) is the author/funder, who has granted bioRxiv a license to display the preprint in perpetuity. It is made available under aCC-BY 4.0 International license.

Short title: Multiplex serosurveillance in coastal Kenya

diphtheria and assays using the multiplex bead format $[31,40]$. Although a WHO reference standard is available for the quantitation of measles virus-neutralizing antibody responses using the whole virus Plaque Reduction Neutralization Test (PRNT) (NIBSC 97/648; $3 \mathrm{IU} / \mathrm{ml}$ ), the standard has not been calibrated for use in ELISA format assays [41], and our MBA only detects IgG antibodies to the measles MV-N protein. In independent work using the specific bead set from this study Coughlin et al. (in preparation) determined that an ROC-optimized MFI-bg cutoff value of 178 MFI-bg units provided good sensitivity and specificity compared to the 'gold standard' PRNT.

MBA cutoff estimates for the S. stercoralis NIE assay and for the three LF antigens (Bm33, $\mathrm{Bm} 14$, and $\mathrm{Wb123}$ ) were assigned using a panel of 94 presumed negative sera donated by anonymous adult US citizens with no history of foreign travel. Test values greater than the mean plus three standards deviations of the presumed negative sample values were considered to be positive. For the P. malariae and P. falciparum $\mathrm{MSP}_{19}$ assays, log transformed data were used for the mean plus three standard deviation calculation, and the panel used for the $P$. falciparum cutoff included only 65 of the original 94 US adult volunteers. An ROC curve using sera from 41 stoolconfirmed, anonymous ascariasis patients, 65 of the adult US citizen volunteers and sera from 45 anonymous US children was used to identify the cutoff for the Ascaris Hb MBA. All of the parasitic disease cutoff values were adjusted to account for differences between the instrument used for cutoff determination at the CDC in Atlanta, GA, and the instrument used to assay the Kenyan sample set at KEMRI in Nairobi, Kenya. Two-fold serial dilutions of the same strong positive sera were assayed on both instruments to generate standard curves for cutoff value adjustment.

S. mansoni SEA and Sm25 coupled beads were used in an earlier study, and the adjusted, ROCassigned cutoff values have been reported elsewhere (965 and 38 MFI-bg units, respectively) [29].

We also estimated seropositivity cutoff points for malaria, LF, and helminth antibody responses using the mean plus three standard deviations of a seronegative distribution estimated from the study measurements using finite Gaussian mixture models with two components [42]. 
bioRxiv preprint doi: https://doi.org/10.1101/604181; this version posted April 19, 2019. The copyright holder for this preprint (which was

not certified by peer review) is the author/funder, who has granted bioRxiv a license to display the preprint in perpetuity. It is made available under aCC-BY 4.0 International license.

Short title: Multiplex serosurveillance in coastal Kenya

\section{Statistical analysis}

Mean antibody levels (MFI-bg) were analyzed on the $\log _{10}$ scale due to skewness in their distribution. We estimated age-dependent mean antibody levels and seroprevalence for each study community using cross-validated, ensemble machine learning, with a library that included the simple mean, linear models, locally weighted regression (loess), and smoothing splines with 2 to 10 degrees of freedom, selected using 10-fold cross-validation [43]. We estimated age-adjusted geometric mean antibody levels and seroprevalence for each community using targeted maximum likelihood estimation with influence curve-based standard errors [43]. In cases where seroprevalence approached zero, we estimated exact binomial confidence intervals. Analyses were conducted using R version 3.3.1, and full replication files (data, scripts) are available through the Open Science Framework (https://osf.io/taknp).

\section{Results}

Antibody measurements were obtained from 2,837 individuals (range 271 - 297 per community) (S1 Fig). Antibody distributions varied by pathogen and antigen, and overall there was good concordance between seropositivity cutoff values for malaria, LF and helminth antibody responses derived through ROC curve analysis or mean plus 3 standard deviation calculations and those derived by Gaussian mixture model analysis (Figure 1). We therefore relied on cutoff values derived from the Gaussian mixture model antibody responses for comparability to future studies that may not have access to positive and negative control specimens. Age-dependent patterns and community-level estimates of mean antibody levels and seroprevalence were highly consistent (S2 Fig, S3 Fig, S4 Fig, S5 Fig, S6 Fig), so we report results based on mean antibody levels in supporting information.

\section{Antifilarial antibody measurements}


bioRxiv preprint doi: https://doi.org/10.1101/604181; this version posted April 19, 2019. The copyright holder for this preprint (which was

not certified by peer review) is the author/funder, who has granted bioRxiv a license to display the preprint in perpetuity. It is made available under aCC-BY 4.0 International license.

Short title: Multiplex serosurveillance in coastal Kenya

Individuals who tested positive for LF infection by ICT had higher mean levels of antibody responses against the 3 recombinant filarial antigens (S7 Fig). Antibody seroprevalence against all 3 recombinant filarial antigens were significantly higher in Ndau Island compared to other communities and the difference in seroprevalence in Ndau compared to other communities was greater among persons less than 30 years old (Figure 2). Antifilarial antibody responses against Bm14 antigen continued to increase with age in all communities. For Wb123, seroprevalence gradually increased with age in Ndau and increased from around the age of 30 - 35 years in Mwadimu community. Compared to the other communities, Jaribuni had slightly elevated mean antibody responses against $\mathrm{Wb} 123$ and $\mathrm{Bm} 33$ antigens ( $p<0.0001)$, but not for $\mathrm{Bm} 14$ antigen $(p=0.08)$. Amongst the youngest children, quantitative antibody levels differentiated communities more clearly than seroprevalence owing to high variability in seroprevalence estimates from the small sample sizes in the youngest age strata (S8 Fig). Elevated antibody levels among young children in Ndau, and possibly Jaribuni, were consistent with ongoing LF transmission.

\section{Antibody responses to other parasite antigens}

Antibody responses to the $P$. falciparum CSP and MSP- $1_{19}$ antigens and to the $P$. malariae MSP-1 $1_{19}$ antigen increased with age in communities in Kilifi and Kwale counties, with higher seroprevalence in Jaribuni community compared to other communities in Kilifi ( $p<0.0001$, Figure 3). Mean antibody responses against $P$. malariae MSP- $1_{19}$ antigen also increased with age and were highest in Jaribuni $(p<0.0001)$, but very low in Ndau Island and Kipini communities $(p<0.0001$ for difference with other communities).

Antibody responses against Schistosoma mansoni Sm25 recombinant antigen were primarily detected in Kimorigo community, and the seroprevalence increased gradually with age, reaching a peak at around 25 years of age (Figure 4). However, although antibody responses to S. mansoni SEA antigen also increased with age in Kimorigo community and mean seroprevalance was higher, there were some responses against this antigen in many other communities. 
bioRxiv preprint doi: https://doi.org/10.1101/604181; this version posted April 19, 2019. The copyright holder for this preprint (which was

not certified by peer review) is the author/funder, who has granted bioRxiv a license to display the preprint in perpetuity. It is made available under aCC-BY 4.0 International license.

Short title: Multiplex serosurveillance in coastal Kenya

Steady increases in S. stercoralis NIE seroprevalence with age were observed and community level mean seroprevalence ranged between $3 \%$ and $26 \%$ (Figure 5). There was heterogeneity in agedependent Ascaris $\mathrm{Hb}$ seroprevalence patterns across communities, with seroprevalence increasing with age in some communities and decreasing with age in others (Figure 5).

\section{Immune responses to vaccine preventable diseases}

Immune response against measles MV-N antigen increased with age, but two communities in Kwale County (Mirihini and Mwadimu) had $<90 \%$ seroprotection (Figure 6). Immune responses to diphtheria toxoid were relatively higher among children, but waned slightly around the ages of 30-40 years before increasing slightly. Generally, diphtheria seroprotection ranged between $22-44 \%$ across communities, and partial protection (defined as responses of 0.01-0.099 IU/ml) ranged between 70$88 \%$ across communities. Immune responses against tetanus toxoid decreased by age in all communities until around 15 years when the levels increased again. Tetanus seroprotection was lower in all 3 communities in Kwale County.

\section{Discussion}

Many established national parasitic disease control and elimination programmes conduct routine surveillance to monitor and evaluate the impact of their targeted interventions. Epidemiologic surveillance systems that enable integrated surveillance and monitoring of coendemic diseases and public health interventions could provide cost-effective synergy to support public health programs [20]. Antibodies can provide valuable information about past exposure to pathogens, and can be helpful for characterizing transmission dynamics in an area to help prioritize where and what interventions are needed the most $[23,44]$.

The LF survey in coastal region of Kenya, which provided the opportunity to collect information for this study, demonstrated that Ndau Island in Lamu County had the highest prevalence of CFA by ICT [17]. The antifilarial antibody measurements assessed by MBAs closely aligned with the CFA results. Ndau Island had the highest levels of antibody responses to all three 
Short title: Multiplex serosurveillance in coastal Kenya

recombinant antifilarial antigens, which confirms the observation that LF transmission is currently higher in Ndau Island compared to the other communities. Previous studies have demonstrated a spatial relationship between antibody-positive individuals and infected persons [45]. The high seroprevalence rates in Ndau, especially among children, are consistent with the conclusion that transmission is ongoing and not yet halted by the MDA campaign.

Antibody responses against $\mathrm{Bm} 14$ antigen continued to increase with age in all villages, which may have been an indication of cumulative exposure to $W$. bancrofti, and also likely reflects historic transmission. Generally, antibody responses against the three recombinant filarial antigens were higher among with CFA-positive individuals than in CFA-negative persons although the difference was relatively smaller for Bm33 (see Fig. S7). Results from a recent study in American Samoa demonstrated that PCR-positive pools of LF vector mosquitoes were statistically significant predictors of seropositivity for Wb123 but not Bm14, suggesting Wb123 could be an indicator of ongoing transmission [46]. Longitudinal studies in areas of intense LF transmission have shown that children acquire infections early in life $[47,48]$. Additionally, previous studies have demonstrated that antibody response against infective stage filarial larvae antigen Wb123 is a specific measure of Wuchereria bancrofti infection, and reduction in both antibody prevalence and transmission is seen most clearly in young children $[49,50]$. Quantitative antifilarial antibody responses among youngest children (2-5 yr, 6-10yr) provided much higher resolution distinctions between communities compared with seroprevalence using the same antigens or the ICT test (S8 Fig) - a result consistent with a recent analysis across diverse pathogens in low transmission settings where seropositive individuals are rare [43]. The higher resolution of quantitative antibody responses compared with seroprevalence, particularly when measured in small sampling clusters, suggests that quantitative antibody levels could serve as an important and more sensitive indicator of recent exposure in sentinel populations of young children, and may be valuable tool for surveillance in the context of lymphatic filariasis elimination programs [19]. Thus, combined measurement of these markers may 
bioRxiv preprint doi: https://doi.org/10.1101/604181; this version posted April 19, 2019. The copyright holder for this preprint (which was

not certified by peer review) is the author/funder, who has granted bioRxiv a license to display the preprint in perpetuity. It is made available under aCC-BY 4.0 International license.

Short title: Multiplex serosurveillance in coastal Kenya

be suitable for characterization of LF transmission settings particularly towards the end of the program when the infection prevalence is very low.

There was high heterogeneity in malaria seroprevalence among the study communities with Kwale and Kilifi counties generally showing relatively higher malaria transmission compared to the other 3 counties. The community mean seroprevalence values suggested that both $P$. falciparum and P. malariae transmission were highest in Jaribuni community in Kilifi County. These differences may reflect environmental heterogeneity in malaria larval breeding sites. A previous study in Kilifi and Kwale counties identified the primary vectors of malaria along the coast of Kenya to include Anopheles funestus and three members of the An. gambiae complex: An. gambiae s.s., An. arabiensis, and An. merus [51]. The study also showed that relatively high malaria parasite prevalence can occur at low and even non-detectable levels of entomological inoculation rates (EIR), suggesting that measurement of EIR may be a relatively insensitive indicator of malaria transmission in some settings. Although malaria parasite prevalence and/or EIR have traditionally been used for reporting malaria transmission intensity [52], serological markers have increasingly been recognized as useful indicators for estimating malaria transmission intensity, which is key for assessing the impact of control interventions [53-56]. Because of the longevity of the specific antibody response, seroprevalence reflects cumulative exposure and thus is less affected by seasonality or unstable transmission [57].

In Kenya, Schistosoma haematobium is highly endemic along the coast where human exposure occurs primarily at pond and stream snail habitats $[9,58,59]$. The absence of $S$. mansoni from most of the Kenyan coastal region is attributable to the absence of the Biomphalaria spp. intermediate-host snails [60]. In Mikinduni Community, along the lower Tana River, crude antigen SEA antibody responses were observed, but S. mansoni-specific Sm 25 responses were lacking. In contrast, Taveta area in Taita-Taveta County is known to be endemic for both S. haematobium and S. mansoni infections [61,62], and this is reflected in the high SEA and Sm25 antibody responses we observed in Kimorigo, a community located on the banks of the shallow freshwater Lake Jipe. The 
bioRxiv preprint doi: https://doi.org/10.1101/604181; this version posted April 19, 2019. The copyright holder for this preprint (which was

not certified by peer review) is the author/funder, who has granted bioRxiv a license to display the preprint in perpetuity. It is made available under aCC-BY 4.0 International license.

Short title: Multiplex serosurveillance in coastal Kenya

absence of S. mansoni species-specific antibody responses to Sm25 recombinant antigen in all of the communities except Kimorigo confirms that S. mansoni infection is likely absent from the lower coastal areas. Thus, S. mansoni Sm 25 recombinant antigen seems to be an excellent antigen for measuring antibody responses to S. mansoni infection [63], and SEA antigen likely detects antibody responses caused by both Schistosoma species by virtue of cross-reactivity.

Presence of responses to $S$. stercoralis NIE antigen is noteworthy because there has been little information on the geographic distribution of this helminth in Kenya due to diagnostic limitations. Copromicroscopic diagnostic methods commonly used in soil-transmitted helminthiasis prevalence studies are inadequate for S. stercoralis detection [64], and thus its distribution in many areas is unknown. Concentration methods, namely the Baermann technique and Koga agar plate culture, have better but still unsatisfactory sensitivity [65]. A study employing NIE serology in Argentina found no cross-reactivity between S. stercoralis and infections with A. lumbricoides, hookworms, or H. nana, and the presence of other helminths in the stool did not affect the $S$. stercoralis-specific antibody responses [66]. A study comparing five serologic tests identified NIELuciferase Immunoprecipitation System to be the most accurate assay for the diagnosis of $S$. stercoralis infection [67]. Previous studies using the recombinant NIE have documented high seroprevalence of S. stercoralis infection in remote Australian Indigenous communities and suggest that collection of dried blood spots may be a useful approach for field diagnosis of $S$. stercoralis seroprevalence $[68,69]$. This study, therefore, provides evidence for possible low-level transmission of S. stercoralis in coastal Kenya as the seroprevalence varies from community to community. Community mean antibody responses to the Ascaris $\mathrm{Hb}$ native antigen and seroprevalence exhibited high heterogeneity among the study communities. A population-based study in Indonesia has shown that an assay for antibodies to Ascaris $\mathrm{Hb}$ is useful for assessing transmission of Ascaris infections, and community antibody rates decreased rapidly following MDA of anthelmintic drugs. The decrease was also found to reflect reduced egg excretion at the community level [33]. 
Short title: Multiplex serosurveillance in coastal Kenya

Vaccination is one of the most one of the most cost-effective public health interventions available, and the epidemiology and burden of vaccine-preventable diseases vary by country and by region partly because of differences in vaccine uptake [70]. This multiplex integrated serosurveillance study identified heterogeneity in serologic antibody levels against measles, diphtheria, and tetanus antigens. Our study demonstrates a need for regularly monitoring serological responses to vaccination programs in resource-poor settings where coverage may be low.

Some of the limitations of this study are somewhat similar to those highlighted previously [23]. Serological studies are traditionally faced with the challenge of establishing diagnostic cutoff points especially when well-characterized positive and negative serum samples are not available. Finite Gaussian mixture models applied in this study led to cutoff values that were very similar to those derived through ROC curves or from mean plus 3 standard deviation calculations for malaria, LF and helminth antibody responses (Fig 1). This result is consistent with a recent, multi-country comparison of cutoff methodology for trachoma antibodies [71], and supports the use of finite mixture models to identify seropositivity cutoffs in studies without access to panels of known positive and negative specimens. For pathogens where cutoff values fall in the centre of a unimodal distribution and it is more difficult to distinguish seropositive and seronegative groups (e.g., A. suum $\mathrm{Hb}$ in Fig 1 ), the use of community mean antibody levels avoids the requirement of choosing a cutoff, and observed antibody response patterns were very consistent with seroprevalence estimates across all of the antibodies tested in this study (S2-S6 Figs). Another limitation of this study is potential for antibody cross-reactivity. Since the coastal area has a typical tropical climate, it is likely that a plethora of pathogens are coincident, some with potentially cross-reactive antigens. A previous study reported that cross-reactivity of the Ascaris $\mathrm{Hb}$ native antigen with hookworm and possibly S. stercoralis and Toxocara spp. limited its value in serology if one is interested in ascariasis alone [33]. Thus, further studies are required to identify sensitive and specific recombinant antigens that could be used with more confidence in serological assays. 
bioRxiv preprint doi: https://doi.org/10.1101/604181; this version posted April 19, 2019. The copyright holder for this preprint (which was

not certified by peer review) is the author/funder, who has granted bioRxiv a license to display the preprint in perpetuity. It is made available under aCC-BY 4.0 International license.

Short title: Multiplex serosurveillance in coastal Kenya

In spite of these limitations this study employed a single multiplex integrated serological assay and analysis methodology to measure antibody levels against several pathogens. There was no need to run separate assays for each pathogen, and we did not need to develop different mathematical models for each pathogen in order to compare exposure across communities and counties. The study highlighted overlap in pathogen burden that would not necessarily have been detected through single-disease surveillance. For example, Ndau Island was found to have the highest LF seroprevalence, but it also had highest Ascaris seroprevalence, thus supporting integrated control of these two helminths. Interestingly, Ndau had almost no evidence for $P$. falciparum malaria transmission. On the other hand Jaribuni community was found to stand out in terms of malaria, LF, and Strongyloides. Multiplex, integrated surveillance has the potential to enable us to look across diseases for opportunities for integrated control, thus providing synergy to global public health initiatives.

\section{Conclusion}

This study highlighted the utility of the MBA platform for integrated serosurveillance of biomarkers of diseases of public health importance. The multiplex integrated serologic assay has the potential to become an invaluable tool for integrated monitoring of trends in endemicity of diseases of public health importance and the effectiveness of public health control programs. 
bioRxiv preprint doi: https://doi.org/10.1101/604181; this version posted April 19, 2019. The copyright holder for this preprint (which was not certified by peer review) is the author/funder, who has granted bioRxiv a license to display the preprint in perpetuity. It is made available under aCC-BY 4.0 International license.

Short title: Multiplex serosurveillance in coastal Kenya

\section{Figure Legends}

Figure 1: Distribution of quantitative antibody levels measured in 10 communities in Kenya's coastal region, 2015. Antibody response measured in multiplex using median fluorescence units minus background (MFI-bg) on a BioRad Bio-Plex platform. Seroprotection cutoff points for measles, diphtheria, and tetanus estimated using a standard curve from WHO reference standards. Seropositive cut points for other antigens estimated using negative control serum samples (solid) and finite Gaussian mixture models (dashed). There was no negative control cutoff point determined for the $P$. falciparum CSP antigen. Table S1 includes cutoff values. The script that created this figure is here: https://osf.io/d9jr.

Figure 2: Lymphatic filariasis antibody age-dependent seroprevalence and overall means, stratified by community in Kenya's coastal region, 2015. Community-level mean seroprevalence is ageadjusted and error bars represent $95 \%$ confidence intervals. Figure $\mathrm{S} 2$ is an extended version of this figure that also includes quantitative antibody levels. The script that created this figure is here: https://osf.io/5zkxw.

Figure 3: Malarial antibody age-dependent seroprevalence and overall means, stratified by community in Kenya's coastal region, 2015. Community-level mean seroprevalence is age-adjusted and error bars represent $95 \%$ confidence intervals. Figure S3 is an extended version of this figure that also includes quantitative antibody levels. The script that created this figure is here: https://osf.io/kzfd3.

Figure 4: Schistosomiasis antibody age-dependent seroprevalence and overall means, stratified by community in Kenya's coastal region, 2015. Community-level mean seroprevalence is age-adjusted and error bars represent $95 \%$ confidence intervals. Figure $\$ 4$ is an extended version of this figure that also includes quantitative antibody levels. The script that created this figure is here:

https://osf.io/tpcg7.

Figure 5: Age-dependent seroprevalence and overall mean for antibodies to $\mathrm{S}$. stercoralis and $A$. lumbricoides, stratified by community in Kenya's coastal region, 2015. Community-level mean seroprevalence is age-adjusted and error bars represent $95 \%$ confidence intervals. Figure S5 is an extended version of this figure that also includes quantitative antibody levels. The script that created this figure is here: https://osf.io/i7ux3.

Figure 6: Age-dependent seroprotection and overall seroprotection for measles, diphtheria, and tetanus stratified by community in Kenya's coastal region, 2015. Community-level seroprotection is age-adjusted and error bars represent $95 \%$ confidence intervals. For diphtheria, we included separate community level estimates of seroprotection (MFI $>4393$ corresponding to $0.1 \mathrm{lU} / \mathrm{ml}$ ) and partial protection (MFI > 183 corresponding to $0.01 \mathrm{IU} / \mathrm{ml}$ ). Figure $\mathrm{S} 6$ is an extended version of this figure that also includes quantitative antibody levels. The script that created this figure is here: https://osf.io/arkhm. 
bioRxiv preprint doi: https://doi.org/10.1101/604181; this version posted April 19, 2019. The copyright holder for this preprint (which was not certified by peer review) is the author/funder, who has granted bioRxiv a license to display the preprint in perpetuity. It is made available under aCC-BY 4.0 International license.

Short title: Multiplex serosurveillance in coastal Kenya

\title{
Supporting Information
}

\author{
S1 Checklist: STROBE checklist.
}

S1 Figure. Community level sample size and age distribution. The script that created this figure is here: https://osf.io/7jxmn.

S2 Figure: Lymphatic filariasis antibody age-dependent mean response and seroprevalence, stratified by community in Kenya's coastal region, 2015. Community-level mean antibody response and seroprevalence are age-adjusted and error bars represent $95 \%$ confidence intervals. Antibody response measured in median fluorescence units minus background (MFI-bg) on a BioRad Bio-Plex platform. The script that created this figure is here: https://osf.io/c79rw.

S3 Figure: Malarial antibody age-dependent mean response and seroprevalence, stratified by community in Kenya's coastal region, 2015. Community-level mean antibody response and seroprevalence are age-adjusted and error bars represent $95 \%$ confidence intervals. Antibody response measured in median fluorescence units minus background (MFI-bg) on a BioRad Bio-Plex platform. The script that created this figure is here: https://osf.io/nhrc2.

S4 Figure: Schistosomiasis antibody age-dependent mean response and seroprevalence, stratified by community in Kenya's coastal region, 2015. Community-level mean antibody response and seroprevalence are age-adjusted and error bars represent $95 \%$ confidence intervals. Antibody response measured in median fluorescence units minus background (MFI-bg) on a BioRad Bio-Plex platform. The script that created this figure is here: https://osf.io/z8v4n.

S5 Figure: Age-dependent mean response and seroprevalence antibodies to $S$. stercoralis and $A$. lumbricoides, stratified by community in Kenya's coastal region, 2015. Community-level mean antibody response and seroprevalence are age-adjusted and error bars represent $95 \%$ confidence intervals. Antibody response measured in median fluorescence units minus background (MFI-bg) on a BioRad Bio-Plex platform. The script that created this figure is here: https://osf.io/spnvx.

S6 Figure: Age-dependent mean response and seroprotection for measles, diphtheria, and tetanus stratified by community in Kenya's coastal region, 2015. Community-level mean antibody response and seroprotection are age-adjusted and error bars represent $95 \%$ confidence intervals. Antibody response measured in median fluorescence units minus background (MFI-bg) on a BioRad Bio-Plex platform. The script that created this figure is here: https://osf.io/uy 5 bf.

S7 Figure: Distribution of three lymphatic filariasis antibodies, stratified by rapid antigen immunochromatographic card test (ICT) results. Boxes mark the median and interquartile range of the distributions. Antibody response measured in median fluorescence units minus background (MFI-bg) on a BioRad Bio-Plex platform. Mann-Whitney U-test $\mathrm{P}<0: 0001$ for differences in antibody responses between ICT negative and positive individuals. The script that created this figure is here: https://osf.io/k9tms.

S8 Figure: Community level estimates of lymphatic filariasis seroprevalence and geometric mean antibody levels among children ages 2-5 and 6-10 years old. Child blood samples were tested the immunochromatographic card test (ICT) and three antigens (Wb123, Bm14, Bm33) measured in median fluorescence units minus background (MFI-bg) on a multiplex BioRad Bio-Plex platform. The mean number of specimens tested per community within each age stratum was 47 (median=47; interquartile range $=39,58$; range $=12,70$ ). The script that created this figure is here:

https://osf.io/xh9yt. 
bioRxiv preprint doi: https://doi.org/10.1101/604181; this version posted April 19, 2019. The copyright holder for this preprint (which was

not certified by peer review) is the author/funder, who has granted bioRxiv a license to display the preprint in perpetuity. It is made available under aCC-BY 4.0 International license.

Short title: Multiplex serosurveillance in coastal Kenya

\section{Acknowledgements}

The authors would like to thank the County Health Departments of Taita-Taveta, Kwale, Kilifi, Tana River and Lamu for supporting the survey, including provision of laboratory technicians and local transportation for the survey teams. The communities of the selected sentinel sites and their local leaders are sincerely thanked for the cooperation and assistance. Drs. Patrick Lammie (CDC) and Simon Brooker (LSHTM) are thanked for useful comments and suggestions throughout the study. We wish to thank members of the Vaccine Preventable Disease Branch (CDC) including Sun Bae Sowers for sharing measles PRNT data. The Kenya Medical Research Institute (KEMRI) provided scientific leadership and oversight for this study.

\section{Disclaimer}

Use of trade names is for identification only and does not imply endorsement by the Public Health Service or by the U.S. Department of Health and Human Services. The findings and conclusions in this report are those of the authors and do not necessarily represent the official position of the Centers for Disease Control and Prevention. 
bioRxiv preprint doi: https://doi.org/10.1101/604181; this version posted April 19, 2019. The copyright holder for this preprint (which was

not certified by peer review) is the author/funder, who has granted bioRxiv a license to display the preprint in perpetuity. It is made available under aCC-BY 4.0 International license.

Short title: Multiplex serosurveillance in coastal Kenya

\section{References}

1. Brooker S, Clements ACA, Hotez PJ, Hay SI, Tatem AJ, Bundy DAP, et al. The co-distribution of Plasmodium falciparum and hookworm among African schoolchildren. Malar J. 2006;5: 1-8. doi:10.1186/1475-2875-5-99

2. Hotez PJ, Molyneux DH, Fenwick A, Ottesen E, Ehrlich Sachs S, Sachs JD, et al. Incorporating a Rapid-Impact Package for Neglected Tropical Diseases with Programs for HIV/AIDS, Tuberculosis, and Malaria. PLoS Med. The World Bank; 2006;3: e102. doi:10.1371/journal.pmed.0030102

3. Molyneux DH, Hotez PJ, Fenwick A. "Rapid-impact interventions": How a policy of integrated control for Africa's neglected tropical diseases could benefit the poor. PLoS Medicine. 2005. pp. 1064-1070. doi:10.1371/journal.pmed.0020336

4. Hürlimann E, Yapi RB, Houngbedji CA, Schmidlin T, Kouadio BA, Silué KD, et al. The epidemiology of polyparasitism and implications for morbidity in two rural communities of Côte d'Ivoire. Parasit Vectors. 2014;7: 81. doi:10.1186/1756-3305-7-81

5. Keiser J, N'Goran EK, Traoré M, Lohourignon KL, Singer BH, Lengeler C, et al. Polyparasitism with Schistosoma mansoni, geohelminths, and intestinal protozoa in rural Côte d'Ivoire. J Parasitol. 2002;88: 461-6. doi:10.1645/0022-3395(2002)088[0461:PWSMGA]2.0.CO;2

6. Raso G, Luginbühl A, Adjoua CA, Tian-Bi NT, Silué KD, Matthys B, et al. Multiple parasite infections and their relationship to self-reported morbidity in a community of rural Cote d'Ivoire. Int J Epidemiol. 2004;33: 1092-1102. doi:10.1093/ije/dyh241

7. Moraga P, Cano J, Baggaley RF, Gyapong JO, Njenga SM, Nikolay B, et al. Modelling the distribution and transmission intensity of lymphatic filariasis in sub-Saharan Africa prior to scaling up interventions: integrated use of geostatistical and mathematical modelling. Parasit Vectors. 2015;8: 560. doi:10.1186/s13071-015-1166-x

8. Munywoki PK, Ohuma EO, Ngama M, Bauni E, Scott JAG, Nokes DJ. Severe Lower Respiratory Tract Infection in Early Infancy and Pneumonia Hospitalizations among Children, Kenya. Emerg Infect Dis. 2013;19: 223-229. doi:10.3201/eid1902.120940

9. Njenga SM, Mwandawiro CS, Muniu E, Mwanje MT, Haji FM, Bockarie MJ. Adult population as potential reservoir of NTD infections in rural villages of Kwale district, Coastal Kenya: implications for preventive chemotherapy interventions policy. Parasit Vectors. 2011;4: 175. doi:10.1186/1756-3305-4-175

10. Okiro EA, Hay SI, Gikandi PW, Sharif SK, Noor AM, Peshu N, et al. The decline in paediatric malaria admissions on the coast of Kenya. Malar J. 2007;6: 151. doi:10.1186/1475-2875-6151

11. WHO. Monitoring and epidemiological assessment of mass drug administration in the global programme to eliminate lymphatic filariasis: a manual for national elimination programmes. World Health Organization, 2011, Geneva, Switzerland.

12. Stolk WA, Swaminathan S, van Oortmarssen GJ, Das PK, Habbema JDF. Prospects for elimination of bancroftian filariasis by mass drug treatment in Pondicherry, India: a simulation study. J Infect Dis. 2003;188: 1371-81. doi:10.1086/378354

13. Michael E, Bundy DA, Grenfell BT. Re-assessing the global prevalence and distribution of lymphatic filariasis. Parasitology. 1996;112 ( Pt 4: 409-28.

14. Sodahlon YK, Dorkenoo AM, Morgah K, Nabiliou K, Agbo K, Miller R, et al. A Success Story: Togo Is Moving toward Becoming the First Sub-Saharan African Nation to Eliminate Lymphatic Filariasis through Mass Drug Administration and Countrywide Morbidity Alleviation. PLoS Negl Trop Dis. 2013;7: e2080. doi:10.1371/journal.pntd.0002080

15. WHO. Togo: first country in sub-Saharan Africa to eliminate lymphatic filariasis. World Health Organization, 2017, Geneva, Switzerland.

http://www.who.int/neglected_diseases/news/Togo_saying_goodbye_lymphatic_filariasis/e $\mathrm{n} /$

16. Njenga SM, Mwandawiro CS, Wamae CN, Mukoko DA, Omar AA, Shimada M, et al. Sustained 
bioRxiv preprint doi: https://doi.org/10.1101/604181; this version posted April 19, 2019. The copyright holder for this preprint (which was not certified by peer review) is the author/funder, who has granted bioRxiv a license to display the preprint in perpetuity. It is made available under aCC-BY 4.0 International license.

Short title: Multiplex serosurveillance in coastal Kenya

reduction in prevalence of lymphatic filariasis infection in spite of missed rounds of mass drug administration in an area under mosquito nets for malaria control. Parasit Vectors. 2011;4: 90. doi:10.1186/1756-3305-4-90

17. Njenga SM, Kanyi HM, Mutungi FM, Okoyo C, Matendechero HS, Pullan RL, et al. Assessment of lymphatic filariasis prior to re-starting mass drug administration campaigns in coastal Kenya. Parasit Vectors. 2017;10: 99. doi:10.1186/s13071-017-2044-5

18. Wipasa J, Suphavilai C, Okell LC, Cook J, Corran PH, Thaikla K, et al. Long-lived antibody and B Cell memory responses to the human malaria parasites, Plasmodium falciparum and Plasmodium vivax. PLoS Pathog. 2010;6: e1000770. doi:10.1371/journal.ppat.1000770

19. Hamlin KL, Moss DM, Priest JW, Roberts J, Kubofcik J, Gass K, et al. Longitudinal monitoring of the development of antifilarial antibodies and acquisition of Wuchereria bancrofti in a highly endemic area of Haiti. PLoS Negl Trop Dis. 2012;6: e1941. doi:10.1371/journal.pntd.0001941

20. Lammie PJ, Moss DM, Brook Goodhew E, Hamlin K, Krolewiecki A, West SK, et al. Development of a new platform for neglected tropical disease surveillance. Int J Parasitol. 2012;42: 797-800. doi:10.1016/j.ijpara.2012.07.002

21. Moss DM, Priest JW, Boyd A, Weinkopff T, Kucerova Z, Beach MJ, et al. Multiplex bead assay for serum samples from children in Haiti enrolled in a drug study for the treatment of lymphatic filariasis. Am J Trop Med Hyg. 2011;85: 229-37. doi:10.4269/ajtmh.2011.11-0029

22. Priest JW, Moss DM, Visvesvara GS, Jones CC, Li A, Isaac-Renton JL. Multiplex assay detection of immunoglobulin $\mathrm{G}$ antibodies that recognize Giardia intestinalis and Cryptosporidium parvum antigens. Clin Vaccine Immunol. 2010;17: 1695-707. doi:10.1128/CVI.00160-10

23. Priest JW, Jenks MH, Moss DM, Mao B, Buth S, Wannemuehler K, et al. Integration of Multiplex Bead Assays for Parasitic Diseases into a National, Population-Based Serosurvey of Women 15-39 Years of Age in Cambodia. PLoS Negl Trop Dis. 2016;10: e0004699. doi:10.1371/journal.pntd.0004699

24. Arnold BF, Priest JW, Hamlin KL, Moss DM, Colford Jr JM, Lammie PJ. Serological Measures of Malaria Transmission in Haiti: Comparison of Longitudinal and Cross-Sectional Methods. PLoS One. 2014;9: e93684. doi:10.1371/journal.pone.0093684

25. Rogier E, Moss DM, Chard AN, Trinies V, Doumbia S, Freeman MC, et al. Evaluation of Immunoglobulin G Responses to Plasmodium falciparum and Plasmodium vivax in Malian School Children Using Multiplex Bead Assay. Am J Trop Med Hyg. 2016; doi:10.4269/ajtmh.16-0476

26. Moss DM, Montgomery JM, Newland S V, Priest JW, Lammie PJ. Detection of Cryptosporidium antibodies in sera and oral fluids using multiplex bead assay. J Parasitol. 2004;90: 397-404. doi:10.1645/GE-3267

27. Rascoe LN, Price C, Shin SH, McAuliffe I, Priest JW, Handali S. Development of Ss-NIE-1 recombinant antigen based assays for immunodiagnosis of strongyloidiasis. PLoS Negl Trop Dis. 2015;9: e0003694. doi:10.1371/journal.pntd.0003694

28. Rogier E, Wiegand R, Moss D, Priest J, Angov E, Dutta S, et al. Multiple comparisons analysis of serological data from an area of low Plasmodium falciparum transmission. Malar J. 2015;14: 436. doi:10.1186/s12936-015-0955-1

29. Won KY, Kanyi HM, Mwende FM, Wiegand RE, Goodhew EB, Priest JW, et al. Multiplex Serologic Assessment of Schistosomiasis in Western Kenya: Antibody Responses in Preschool Aged Children as a Measure of Reduced Transmission. Am J Trop Med Hyg. 2017;96: 14601467. doi:10.4269/ajtmh.16-0665

30. Hummel KB, Erdman DD, Heath J, Bellini WJ. Baculovirus expression of the nucleoprotein gene of measles virus and utility of the recombinant protein in diagnostic enzyme immunoassays. J Clin Microbiol. 1992;30: 2874-80.

31. Scobie HM, Mao B, Buth S, Wannemuehler KA, Sørensen C, Kannarath C, et al. Tetanus Immunity among Women Aged 15 to 39 Years in Cambodia: a National Population-Based Serosurvey, 2012. Clin Vaccine Immunol. 2016;23: 546-54. doi:10.1128/CVI.00052-16 
bioRxiv preprint doi: https://doi.org/10.1101/604181; this version posted April 19, 2019. The copyright holder for this preprint (which was not certified by peer review) is the author/funder, who has granted bioRxiv a license to display the preprint in perpetuity. It is made available under aCC-BY 4.0 International license.

Short title: Multiplex serosurveillance in coastal Kenya

32. Vlaminck J, Nejsum P, Vangroenweghe F, Thamsborg SM, Vercruysse J, Geldhof P. Evaluation of a serodiagnostic test using Ascaris suum haemoglobin for the detection of roundworm infections in pig populations. Vet Parasitol. 2012;189: 267-73.

doi:10.1016/j.vetpar.2012.04.024

33. Vlaminck J, Supali T, Geldhof P, Hokke CH, Fischer PU, Weil GJ. Community Rates of IgG4 Antibodies to Ascaris Haemoglobin Reflect Changes in Community Egg Loads Following Mass Drug Administration. PLoS NegI Trop Dis. 2016;10: e0004532. doi:10.1371/journal.pntd.0004532

34. Benitez A, Priest JW, Ehigiator HN, McNair N, Mead JR. Evaluation of DNA encoding acidic ribosomal protein $\mathrm{P} 2$ of Cryptosporidium parvum as a potential vaccine candidate for cryptosporidiosis. Vaccine. 2011;29: 9239-45. doi:10.1016/j.vaccine.2011.09.094

35. Ballou WR, Rothbard J, Wirtz RA, Gordon DM, Williams JS, Gore RW, et al. Immunogenicity of synthetic peptides from circumsporozoite protein of Plasmodium falciparum. Science. 1985;228: 996-9.

36. Dame JB, Williams JL, McCutchan TF, Weber JL, Wirtz RA, Hockmeyer WT, et al. Structure of the gene encoding the immunodominant surface antigen on the sporozoite of the human malaria parasite Plasmodium falciparum. Science. 1984;225: 593-9.

37. Borrow R, Balmer $\mathrm{P}$, Roper $\mathrm{MH}$. The immunological basis for immunization series Module 3 : Tetanus - Update, 2006. World Health Organization, Geneva, Switzerland. http://apps.who.int/iris/bitstream/10665/43687/1/9789241595551_eng.pdf

38. Kristiansen $M$, Aggerbeck $H$, Heron I. Improved ELISA for determination of anti-diphtheria and/or anti-tetanus antitoxin antibodies in sera. APMIS. 1997;105: 843-53.

39. Scheifele DW, Ochnio JJ. The immunologic basis for immunization series. Module 2: Diphtheria - update 2009. Immunization, Vaccines and Biologicals. Geneva, Switzerland; 2009. http://apps.who.int/iris/bitstream/10665/44094/1/9789241597869_eng.pdf

40. van Gageldonk PGM, von Hunolstein C, van der Klis FRM, Berbers GAM. Improved specificity of a multiplex immunoassay for quantitation of anti-diphtheria toxin antibodies with the use of diphtheria toxoid. Clin Vaccine Immunol. 2011;18: 1183-6. doi:10.1128/CVI.05081-11

41. Bentley M, Christian PD, Cohen BJ, Heath A. Report of a Collaborative Study to Assess the Suitability of a Replacement for the $2^{\text {nd }}$ International Standard for Anti-Measles Sera; WHO/BS/06.2031. Geneva, Switzerland; 2006.

42. Benaglia T, Chauveau D, Hunter DR, Young DS. mixtools: An R Package for Analyzing Mixture Models. J Stat Softw. 2009;32: 1-29.

43. Arnold BF, van der Laan MJ, Hubbard AE, Steel C, Kubofcik J, Hamlin KL, et al. Measuring changes in transmission of neglected tropical diseases, malaria, and enteric pathogens from quantitative antibody levels. PLoS NegI Trop Dis. 2017;11: e0005616.

doi:10.1371/journal.pntd.0005616

44. Lau CL, Won KY, Becker L, Soares Magalhaes RJ, Fuimaono S, Melrose W, et al. Seroprevalence and spatial epidemiology of Lymphatic Filariasis in American Samoa after successful mass drug administration. PLoS Negl Trop Dis. 2014;8: e3297. doi:10.1371/journal.pntd.0003297

45. Joseph H, Maiava F, Naseri T, Silva U, Lammie P, Melrose W. Epidemiological assessment of continuing transmission of lymphatic filariasis in Samoa. Ann Trop Med Parasitol. 2011;105: 567-78. doi:10.1179/2047773211Y.0000000008

46. Lau CL, Won KY, Lammie PJ, Graves PM. Lymphatic Filariasis Elimination in American Samoa: Evaluation of Molecular Xenomonitoring as a Surveillance Tool in the Endgame. PLoS Negl Trop Dis. 2016;10: e0005108. doi:10.1371/journal.pntd.0005108

47. Witt C, Ottesen EA. Lymphatic filariasis: an infection of childhood. Trop Med Int Heal. 2001;6: 582-606.

48. Lammie PJ, Reiss MD, Dimock KA, Streit TG, Roberts JM, Eberhard ML. Longitudinal analysis of the development of filarial infection and antifilarial immunity in a cohort of Haitian children. 
bioRxiv preprint doi: https://doi.org/10.1101/604181; this version posted April 19, 2019. The copyright holder for this preprint (which was not certified by peer review) is the author/funder, who has granted bioRxiv a license to display the preprint in perpetuity. It is made available under aCC-BY 4.0 International license.

Short title: Multiplex serosurveillance in coastal Kenya

Am J Trop Med Hyg. 1998;59: 217-221. doi:10.4269/ajtmh.1998.59.217

49. Kubofcik J, Fink DL, Nutman TB. Identification of Wb123 as an early and specific marker of Wuchereria bancrofti infection. PLoS NegI Trop Dis. 2012;6: e1930. doi:10.1371/journal.pntd.0001930

50. Steel C, Kubofcik J, Ottesen EA, Nutman TB. Antibody to the Filarial Antigen Wb123 Reflects Reduced Transmission and Decreased Exposure in Children Born following Single Mass Drug Administration (MDA). PLoS Negl Trop Dis. 2012;6: e1940. doi:10.1371/journal.pntd.0001940

51. Mbogo CM, Mwangangi JM, Nzovu J, Gu W, Yan G, Gunter JT, et al. Spatial and temporal heterogeneity of Anopheles mosquitoes and Plasmodium falciparum transmission along the Kenyan coast. Am J Trop Med Hyg. 2003;68: 734-742.

52. Pothin E, Ferguson NM, Drakeley $\mathrm{CJ}$, Ghani AC. Estimating malaria transmission intensity from Plasmodium falciparum serological data using antibody density models. Malar J. 2016;15: 79. doi:10.1186/s12936-016-1121-0

53. Wong J, Hamel MJ, Drakeley CJ, Kariuki S, Shi Y, Lal AA, et al. Serological markers for monitoring historical changes in malaria transmission intensity in a highly endemic region of Western Kenya, 1994-2009. Malar J. 2014;13: 451. doi:10.1186/1475-2875-13-451

54. Cook J, Reid H, lavro J, Kuwahata M, Taleo G, Clements A, et al. Using serological measures to monitor changes in malaria transmission in Vanuatu. Malar J. 2010;9: 169. doi:10.1186/14752875-9-169

55. Drakeley CJ, Corran PH, Coleman PG, Tongren JE, McDonald SLR, Carneiro I, et al. Estimating medium- and long-term trends in malaria transmission by using serological markers of malaria exposure. Proc Natl Acad Sci 2005;102: 5108-13. doi:10.1073/pnas.0408725102

56. Dewasurendra RL, Dias JN, Sepulveda N, Gunawardena GSA, Chandrasekharan N, Drakeley C, et al. Effectiveness of a serological tool to predict malaria transmission intensity in an elimination setting. BMC Infect Dis. 2017;17: 49. doi:10.1186/s12879-016-2164-0

57. Badu K, Afrane YA, Larbi J, Stewart VA, Waitumbi J, Angov E, et al. Marked variation in MSP119 antibody responses to malaria in western Kenyan highlands. BMC Infect Dis. 2012;12: 50. doi:10.1186/1471-2334-12-50

58. Njaanake KH, Vennervald BJ, Simonsen PE, Madsen H, Mukoko DA, Kimani G, et al. Schistosoma haematobium and soil-transmitted Helminths in Tana Delta District of Kenya: infection and morbidity patterns in primary schoolchildren from two isolated villages. BMC Infect Dis. 2015;16: 57. doi:10.1186/s12879-016-1387-4

59. Clennon JA, King CH, Muchiri EM, Kariuki HC, Ouma JH, Mungai P, et al. Spatial patterns of urinary schistosomiasis infection in a highly endemic area of coastal kenya. Am J Trop Med Hyg. 2004;70: 443-448.

60. Brown DS, Jelnes JE, Kinoti GK, Ouma J. Distribution in Kenya of intermediate hosts of Schistosoma. Trop Geogr Med. 1981;33: 95-103.

61. Gouvras AN, Kariuki C, Koukounari A, Norton AJ, Lange CN, Ireri E, et al. The impact of single versus mixed Schistosoma haematobium and $S$. mansoni infections on morbidity profiles amongst school-children in Taveta, Kenya. Acta Trop. 2013;128: 309-317. doi:10.1016/j.actatropica.2013.01.001

62. Thiongo FW, Ouma JH. Prevalence of schistosomes and other parasites in Taita division of Taita-Taveta district. East Afr Med J. 1987;64: 665-71.

63. Tsang VC, Hancock K, Kelly MA, Wilson BC, Maddison SE. Schistosoma mansoni adult microsomal antigens, a serologic reagent. II. Specificity of antibody responses to the $S$. mansoni microsomal antigen (MAMA). J Immunol. American Association of Immunologists; 1983;130: 1366-70.

64. Steinmann P, Zhou X-N, Du Z-W, Jiang J-Y, Wang L-B, Wang X-Z, et al. Occurrence of Strongyloides stercoralis in Yunnan Province, China, and Comparison of Diagnostic Methods. PLoS NegI Trop Dis. 2007;1: e75. doi:10.1371/JOURNAL.PNTD.0000075

65. Glinz D, Silué KD, Knopp S, Lohourignon LK, Yao KP, Steinmann P, et al. Comparing Diagnostic 
bioRxiv preprint doi: https://doi.org/10.1101/604181; this version posted April 19, 2019. The copyright holder for this preprint (which was

not certified by peer review) is the author/funder, who has granted bioRxiv a license to display the preprint in perpetuity. It is made available under aCC-BY 4.0 International license.

Short title: Multiplex serosurveillance in coastal Kenya

Accuracy of Kato-Katz, Koga Agar Plate, Ether-Concentration, and FLOTAC for Schistosoma mansoni and Soil-Transmitted Helminths. PLoS Negl Trop Dis. 2010;4: e754.

doi:10.1371/journal.pntd.0000754

66. Krolewiecki AJ, Ramanathan R, Fink V, McAuliffe I, Cajal SP, Won K, et al. Improved diagnosis of Strongyloides stercoralis using recombinant antigen-based serologies in a community-wide study in northern Argentina. Clin Vaccine Immunol. American Society for Microbiology (ASM) 2010;17: 1624-30. doi:10.1128/CVI.00259-10

67. Bisoffi Z, Buonfrate D, Sequi M, Mejia R, Cimino RO, Krolewiecki AJ, et al. Diagnostic Accuracy of Five Serologic Tests for Strongyloides stercoralis Infection. PLoS Negl Trop Dis. 2014;8: e2640. doi:10.1371/journal.pntd.0002640

68. Kearns TM, Currie BJ, Cheng AC, McCarthy J, Carapetis JR, Holt DC, et al. Strongyloides seroprevalence before and after an ivermectin mass drug administration in a remote Australian Aboriginal community. PLoS Negl Trop Dis. 2017;11: e0005607. doi:10.1371/journal.pntd.0005607

69. Mounsey K, Kearns T, Rampton M, Llewellyn S, King M, Holt D, et al. Use of dried blood spots to define antibody response to the Strongyloides stercoralis recombinant antigen NIE. Acta Trop. 2014;138: 78-82. doi:10.1016/j.actatropica.2014.07.007

70. Brenzel L, Wolfson L, Fox-Rushby J, Miller M, Halsey NA. Vaccine-preventable diseases. in: DT Jamison, JG Breman, AR Measham, (Eds.) Disease control priorities in developing countries. 2nd edn. Oxford University Press, New York; 2006: 389-412.

69. Migchelsen SJ, Martin DL, Southisombath K, Turyaguma P, Heggen A, Rubangakene PP, et al. Defining Seropositivity Thresholds for Use in Trachoma Elimination Studies. PLoS Negl Trop Dis. 2017;11: e0005230. doi:10.1371/journal.pntd.0005230. 
Vaccine Preventable

Measles MV-N

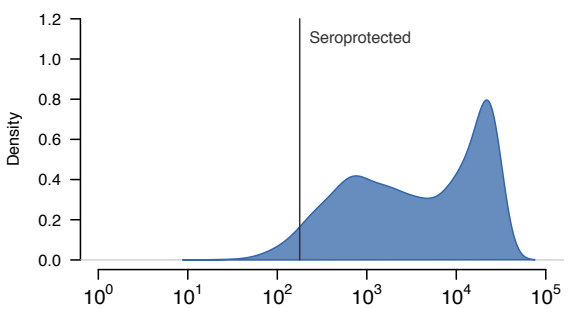

\section{Malaria}

Plasmodium falciparum CSP

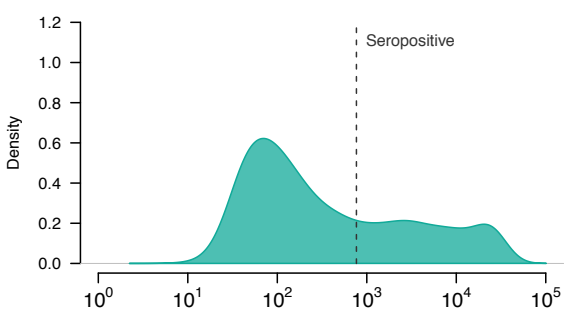

\section{Lymphatic filariasis}

LF Wb123

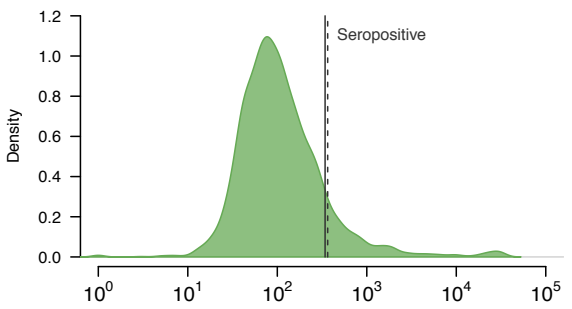

\section{Schistosomiasis}

Schistosoma mansoni SEA

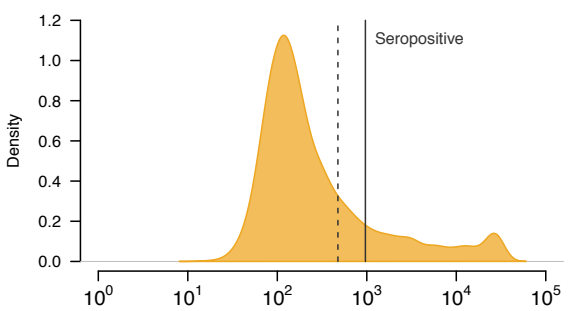

\section{Other helminths}

Strongyloides stercoralis NIE

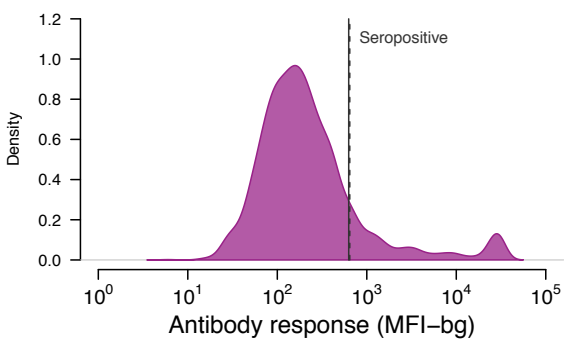

Diphtheria toxoid

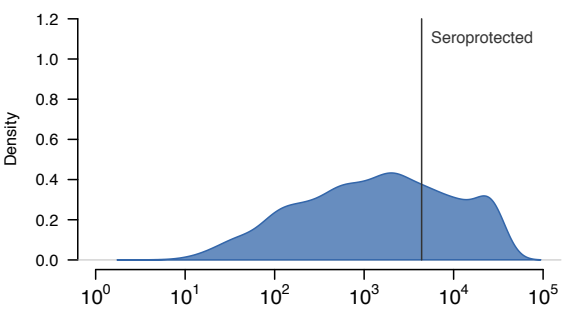

Plasmodium falciparum MSP - $1_{19}$

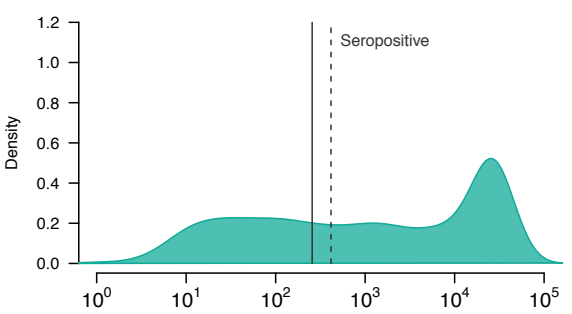

LF Bm14

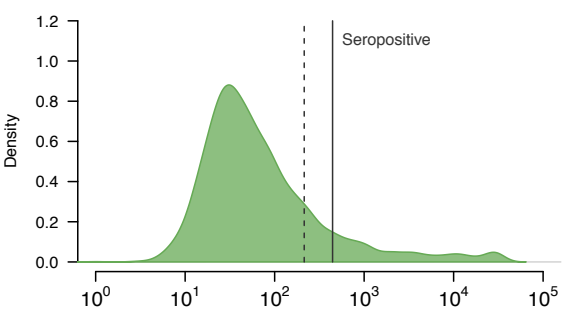

Schistosoma mansoni Sm25

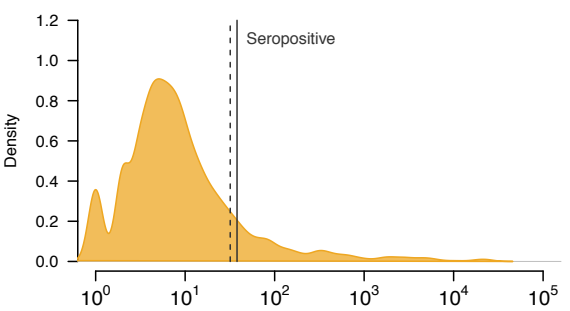

Tetanus toxoid

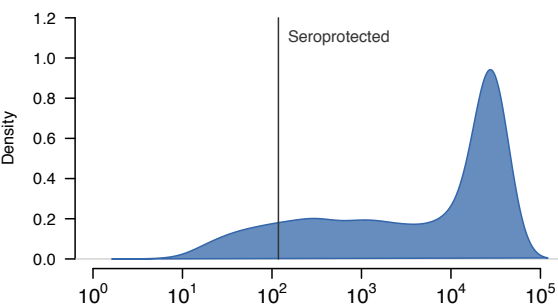

Plasmodium malariae MSP - $1_{19}$

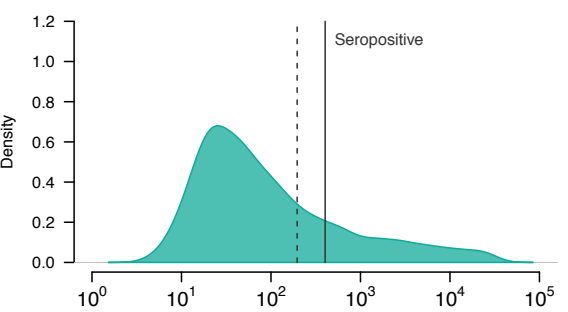

LF Bm33

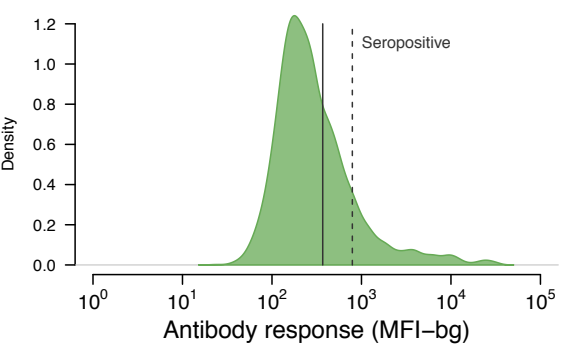

Fig. 1: Distribution of quantitative antibody levels measured in 10 communities in Kenya?s coastal region, 2015. Antibody response measured in multiplex using median fluorescence units minus background (MFI-bg) on a BioRad Bio-Plex platform. Seroprotection cutoff points for measles, diphtheria, and tetanus estimated using a standard curve from WHO reference standards. Seropositive cut points for other antigens estimated using negative control serum samples (solid) and finite Gaussian mixture models (dashed). There was no negative control cutoff point determined for the P. falciparum CSP antigen. Table S1 includes cutoff values. Figure created with computational notebook: https://osf.io/d9jr . 


\section{Lymphatic filariasis Wb123}

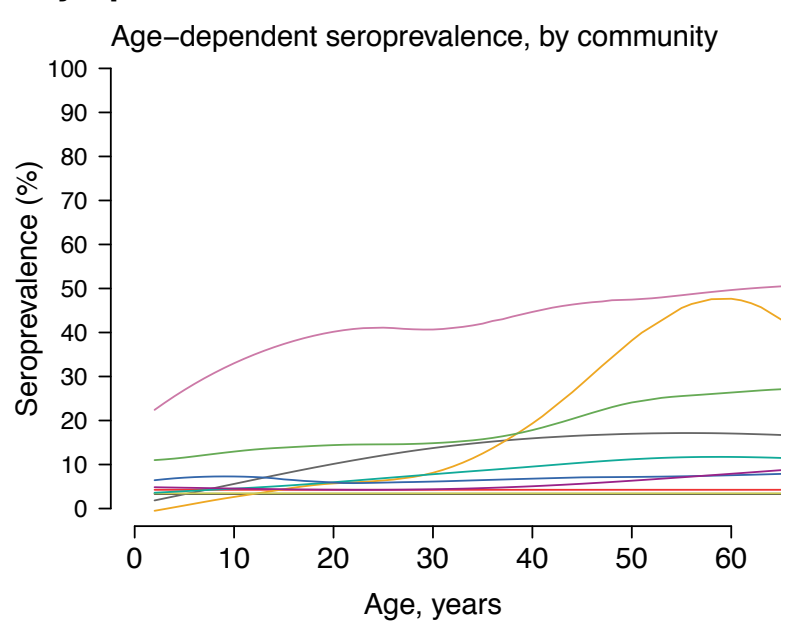

\section{Lymphatic filariasis Bm14}

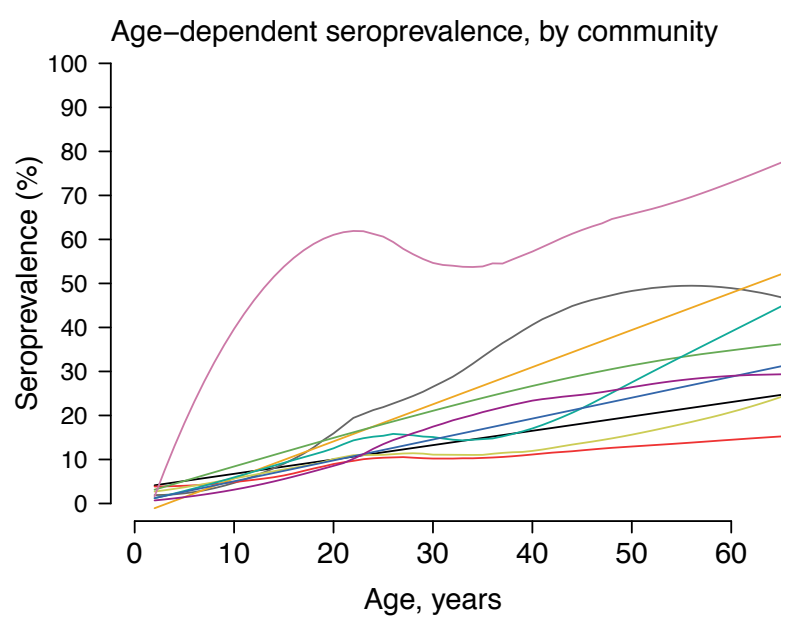

\section{Lymphatic filariasis $\mathrm{Bm} 33$}

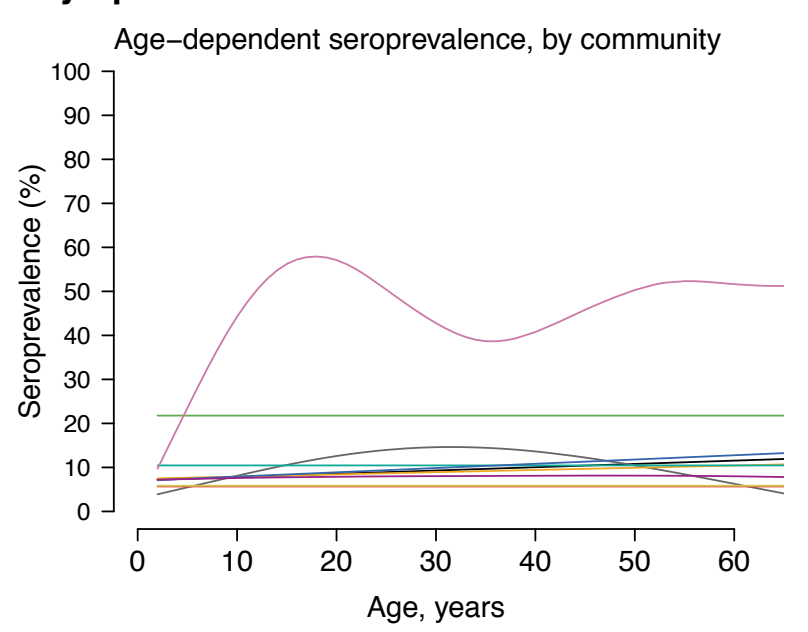

Taita Taveta

1 Kimorigo

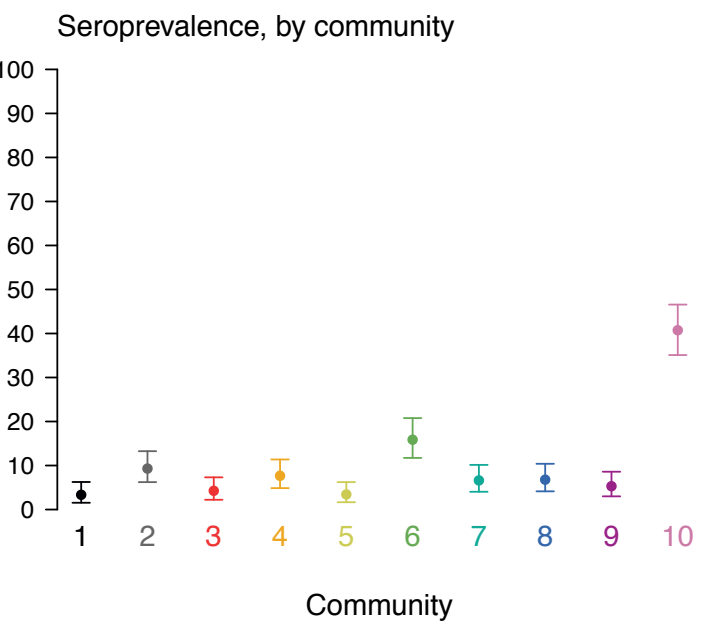

Seroprevalence, by community

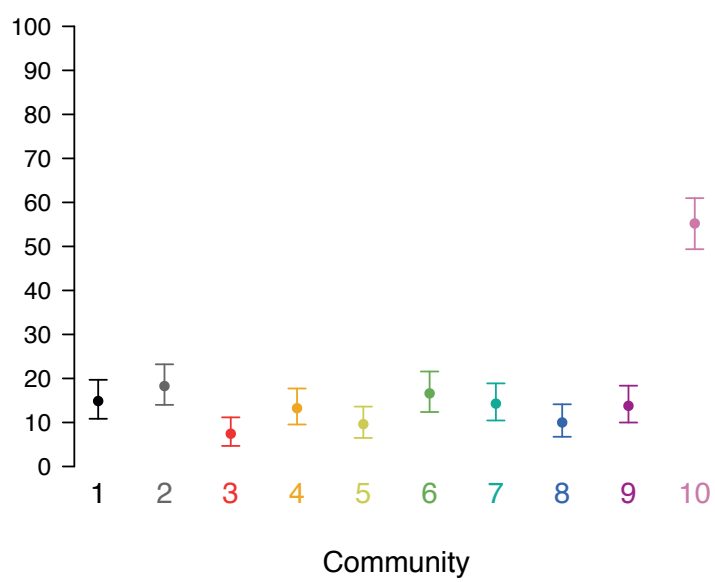

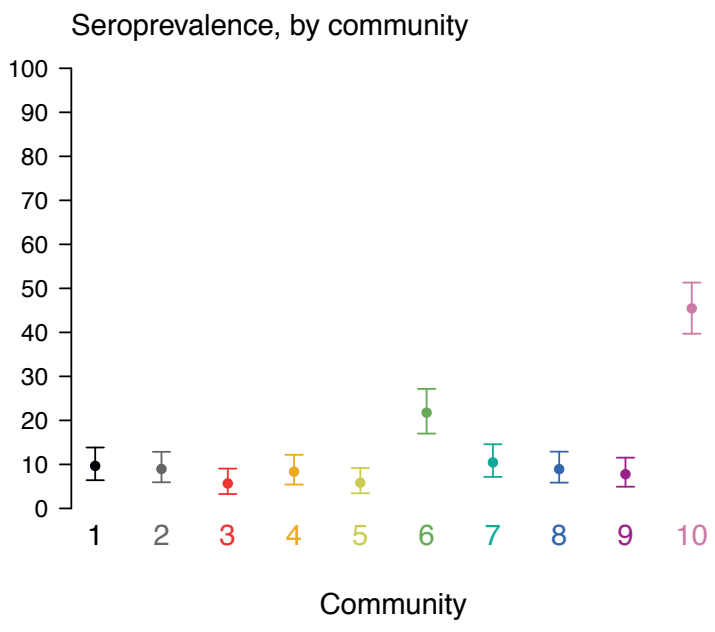

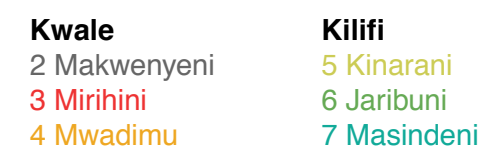

Fig. 2: Lymphatic filariasis antibody age-dependent seroprevalence and overall means, stratified by community in Kenya?s coastal region, 2015. Community-level mean seroprevalence is age-adjusted and error bars represent $95 \%$ confidence intervals. Figure S2 is an extended version of this figure that also includes quantitative antibody levels. Figure created with computational notebook: https://osf.io/5zkxw . 


\section{P. falciparum CSP}

Age-dependent seroprevalence, by community

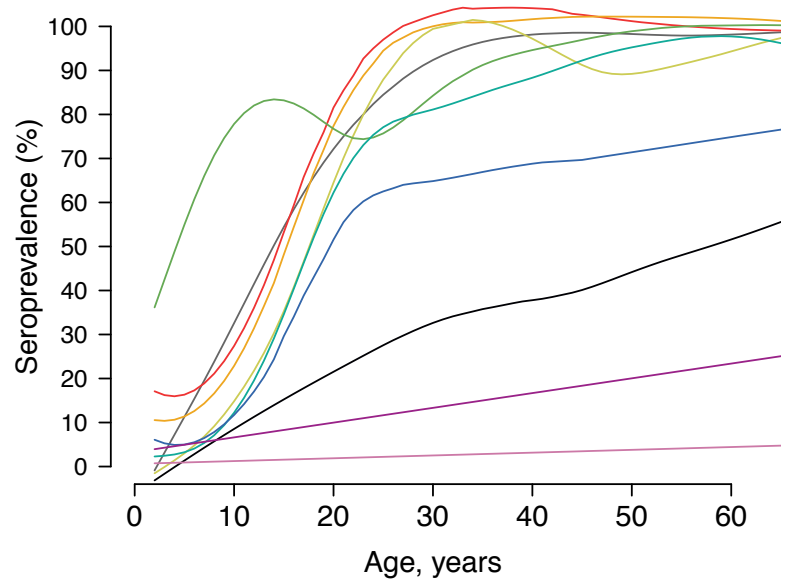

P. falciparum MSP-1

Age-dependent seroprevalence, by community

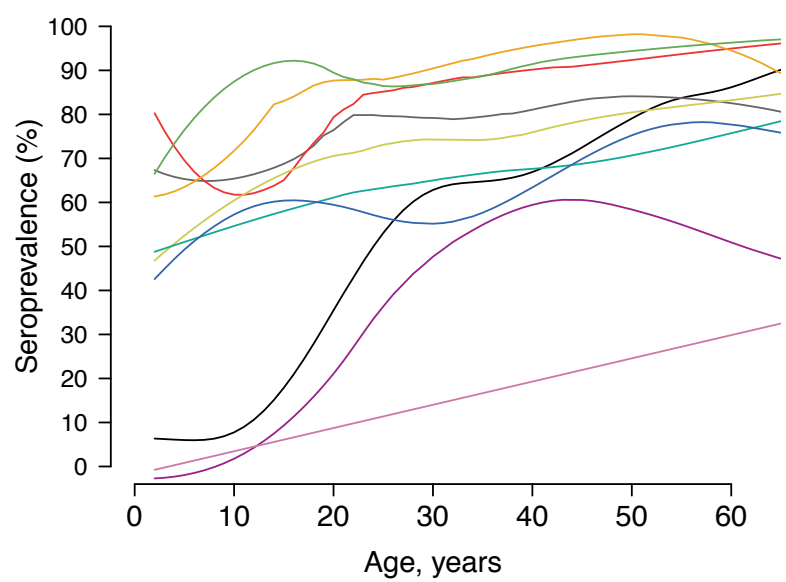

\section{P. malariae MSP-1}

Age-dependent seroprevalence, by community

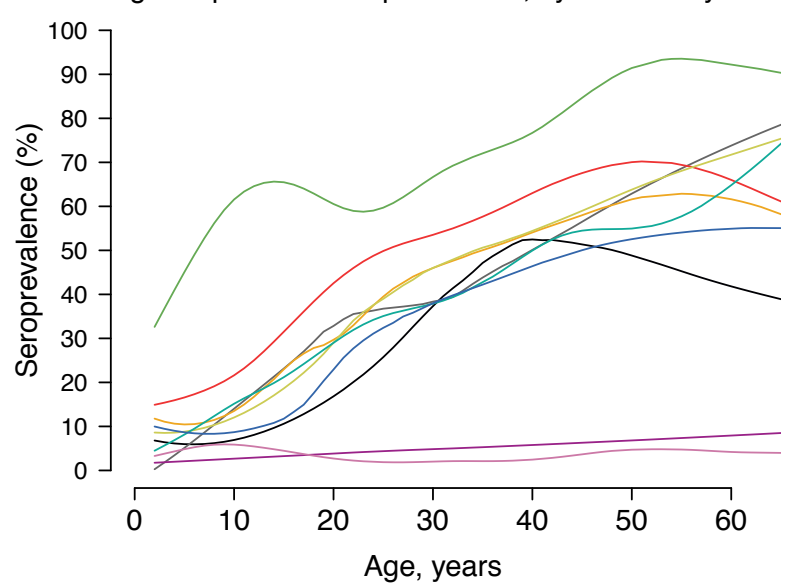

Taita Taveta

1 Kimorigo

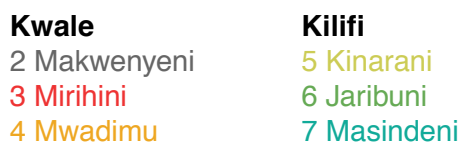

Seroprevalence, by community

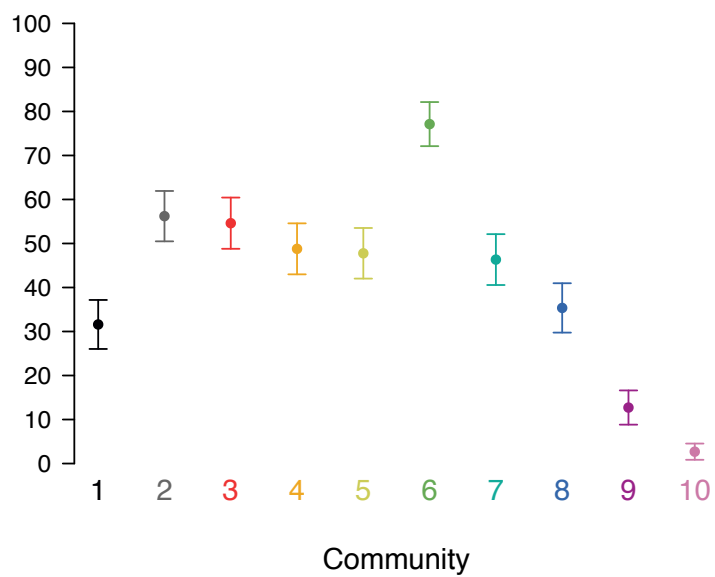

Seroprevalence, by community

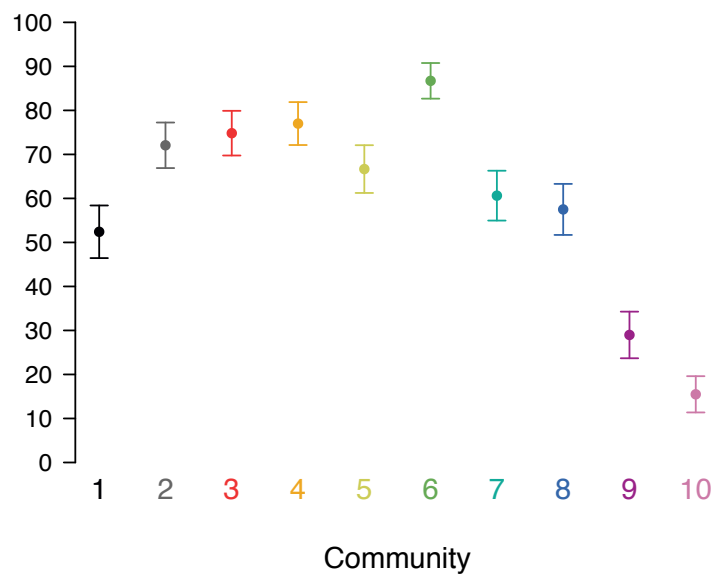

Seroprevalence, by community

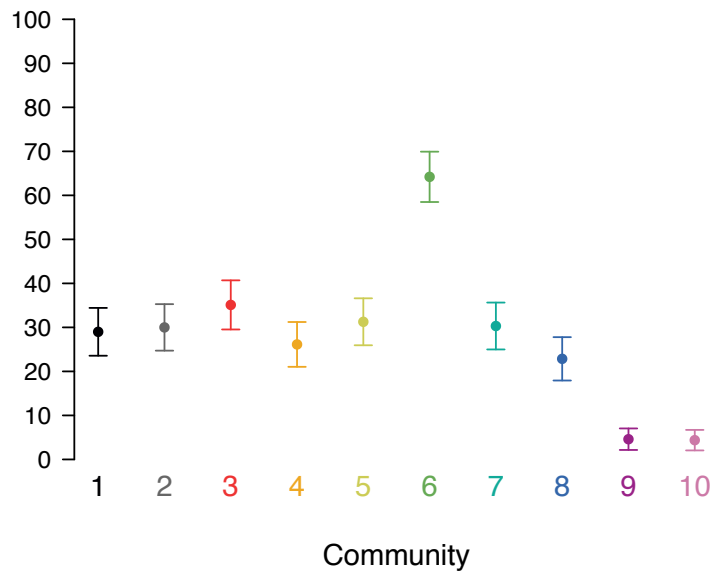

$\begin{array}{ll}\text { Tana River } & \text { Lamu } \\ 8 \text { Mikinduni } & 10 \text { Ndau } \\ 9 \text { Kipini } & \end{array}$

Fig. 3: Malarial antibody age-dependent seroprevalence and overall means, stratified by community in Kenya?s coastal region, 2015. Community-level mean seroprevalence is ageadjusted and error bars represent $95 \%$ confidence intervals. Figure S3 is an extended version of this figure that also includes quantitative antibody levels. Figure created with computational notebook: https://osf.io/kzfd3. 


\section{S. mansoni SEA}

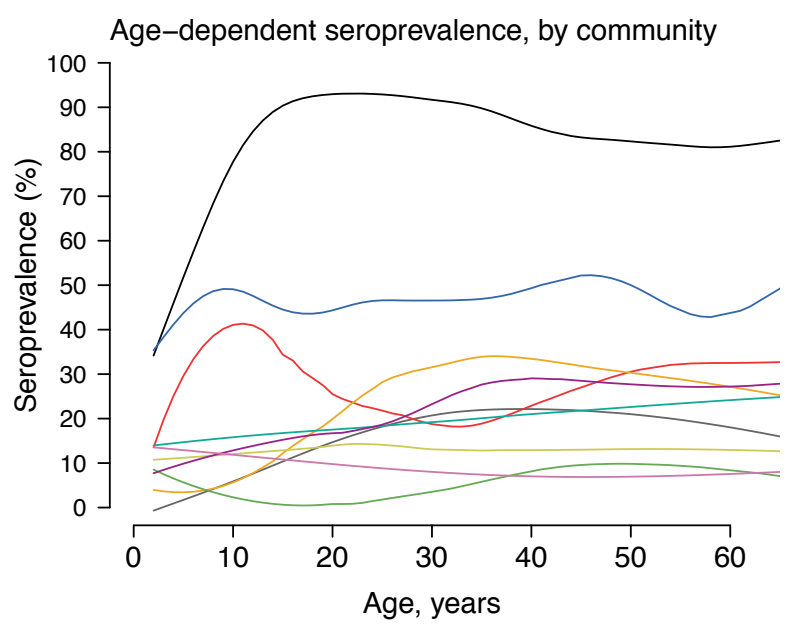

\section{S. mansoni Sm25}

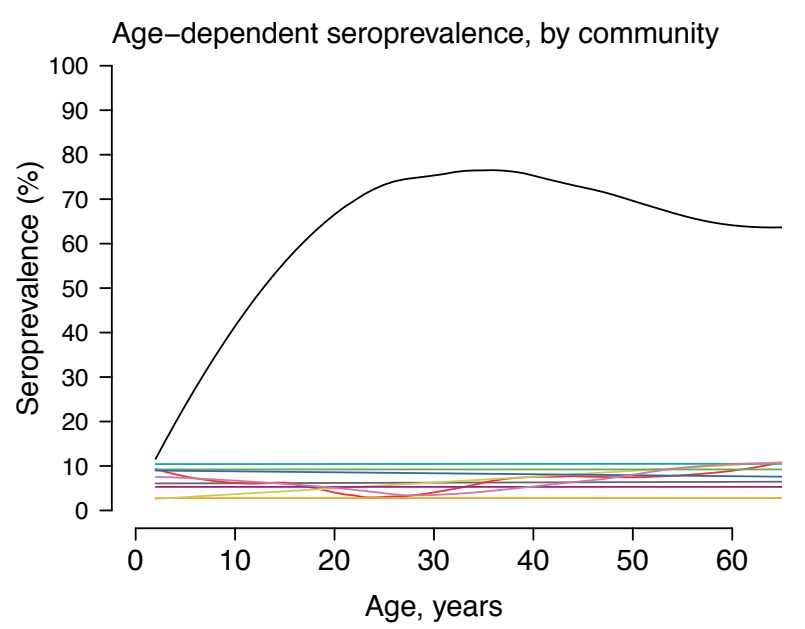

Taita Taveta

1 Kimorigo

$\begin{array}{ll}\text { Kwale } & \text { Kilifi } \\ \text { 2 Makwenyeni } & 5 \text { Kinarani } \\ \text { 3 Mirihini } & 6 \text { Jaribuni } \\ \text { 4 Mwadimu } & 7 \text { Masindeni }\end{array}$

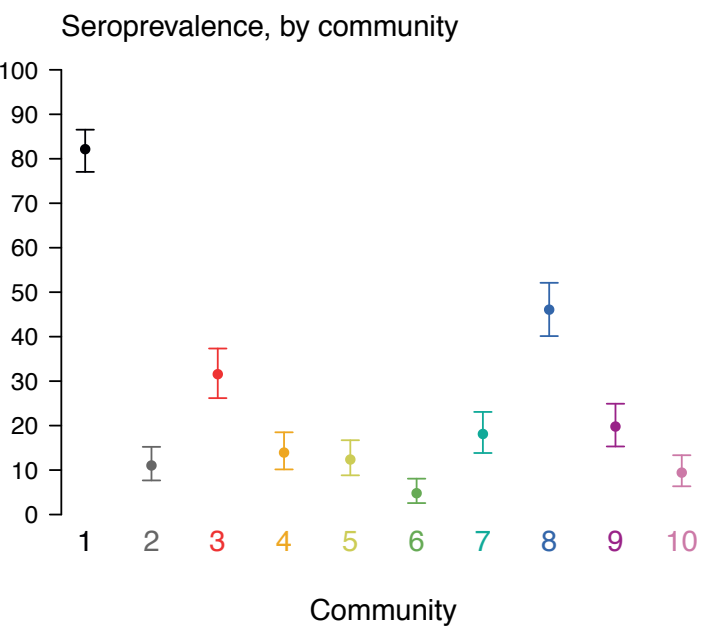

Seroprevalence, by community

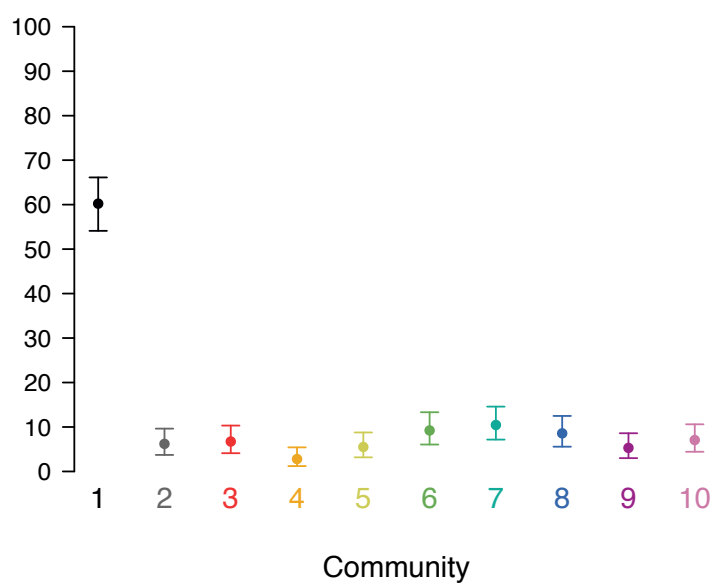

$\begin{array}{ll}\text { Tana River } & \text { Lamu } \\ 8 \text { Mikinduni } & 10 \text { Ndau } \\ 9 \text { Kipini } & \end{array}$

Fig. 4: Schistosomiasis antibody age-dependent seroprevalence and overall means, stratified by community in Kenya?s coastal region, 2015. Community-level mean seroprevalence is ageadjusted and error bars represent 95\% confidence intervals. Figure S4 is an extended version of this figure that also includes quantitative antibody levels. Figure created with computational notebook: https://osf.io/tpcg7 . 


\section{S. stercoralis NIE}

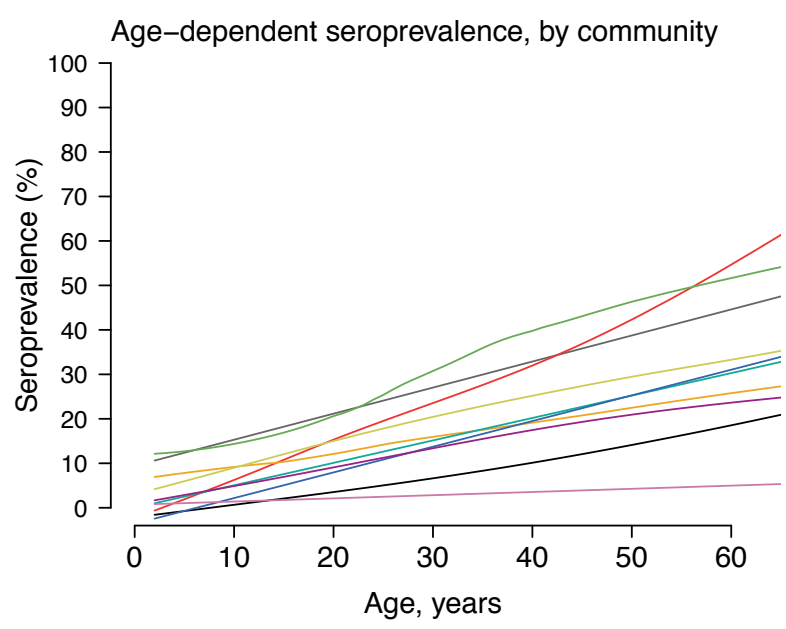

\section{Ascaris AsHb}

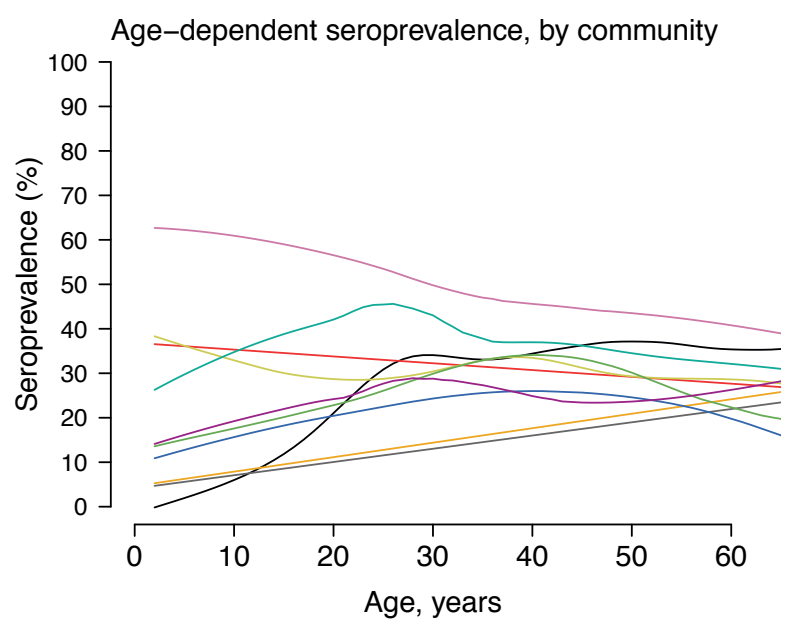

Taita Taveta

1 Kimorigo

\section{Kwale \\ Kilifi}

2 Makwenyeni

3 Mirihini

4 Mwadimu
5 Kinarar

6 Jaribuni

7 Masindeni
Seroprevalence, by community

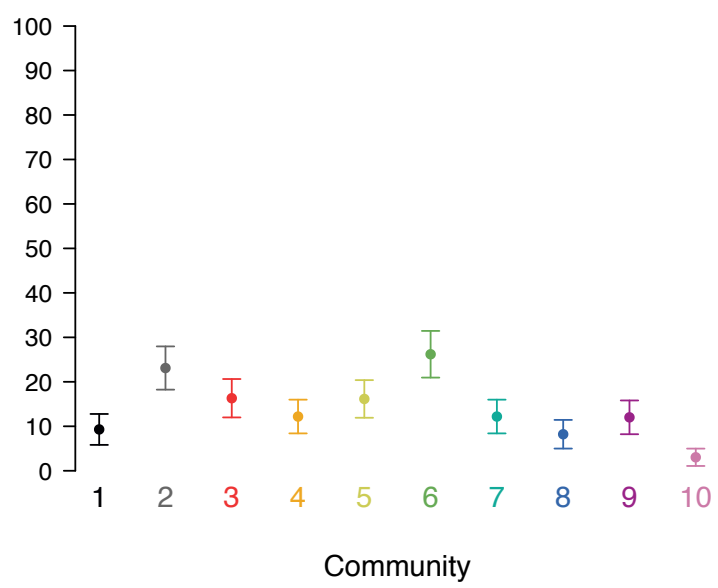

Fig. 5: Age-dependent seroprevalence and overall mean for antibodies to S. stercoralis and A. lumbricoides, stratified by community in Kenya?s coastal region, 2015. Community-level mean seroprevalence is age-adjusted and error bars represent $95 \%$ confidence intervals. Figure S5 is an extended version of this figure that also includes quantitative antibody levels. Figure created with computational notebook: https://osf.io/j7ux3 . 
Measles MV-N

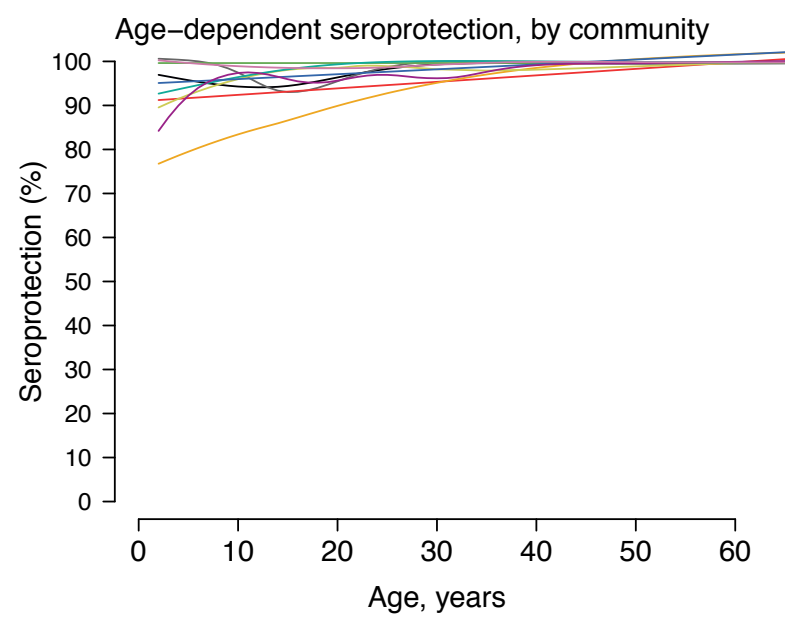

\section{Diphtheria toxoid}

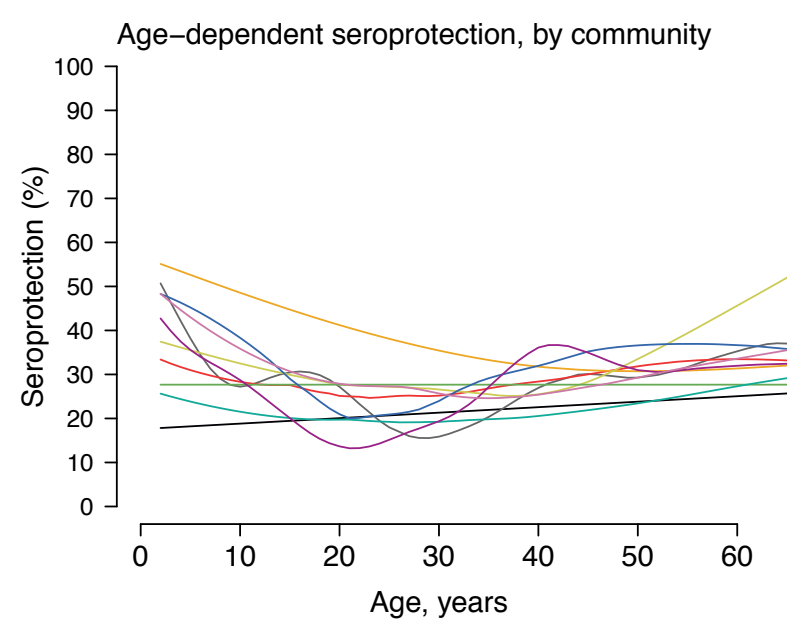

\section{Tetanus toxoid}

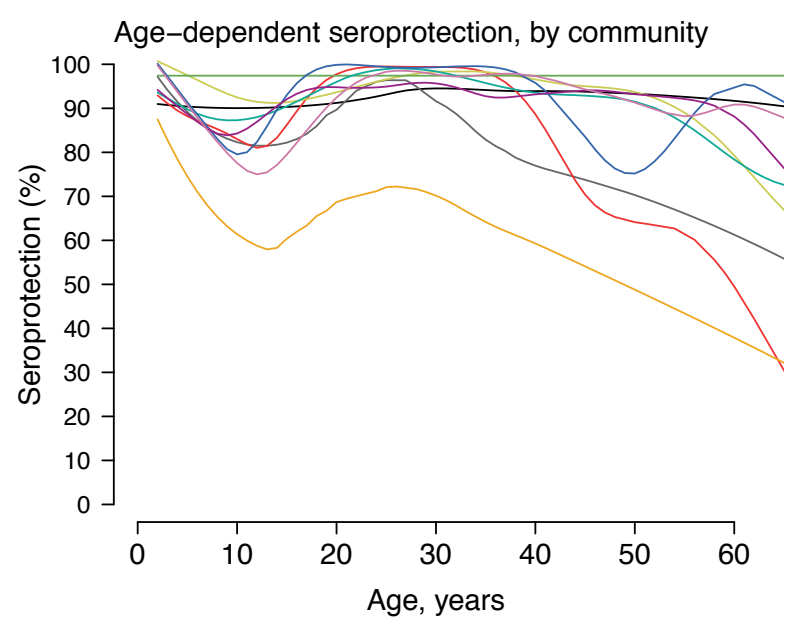

Taita Taveta

1 Kimorigo
Kilifi

5 Kinarani 6 Jaribuni 7 Masindeni
Seroprotection, by community

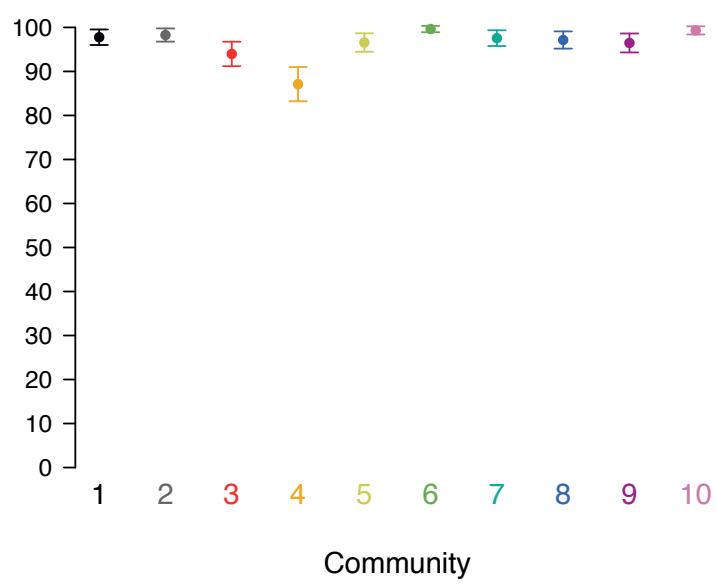

Seroprotection and partial protection, by community

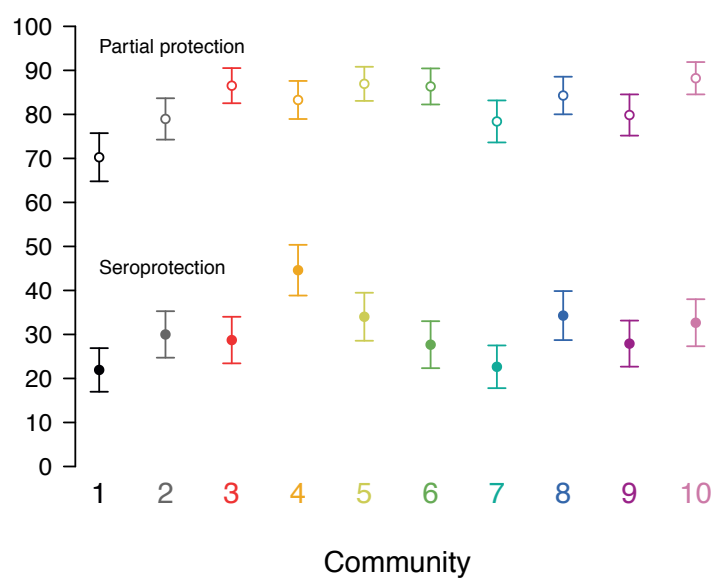

Seroprotection, by community

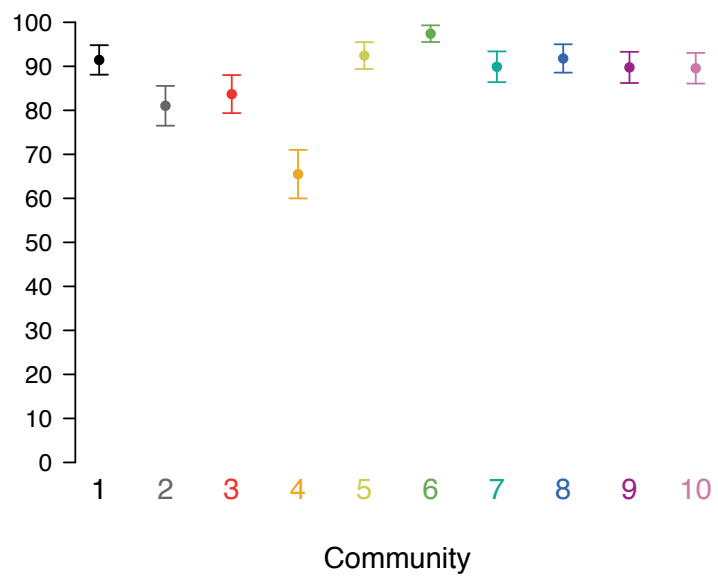

Tana River

8 Mikinduni

Lamu

9 Kipini

Fig. 6: Age-dependent seroprotection and overall seroprotection for measles, diphtheria, and tetanus stratified by community in Kenya?s coastal region, 2015. Community-level seroprotection is age-adjusted and error bars represent $95 \%$ confidence intervals. For diphtheria, we included separate community level estimates of seroprotection (MFI > 4393 corresponding to $0.1 \mathrm{IU} / \mathrm{ml}$ ) and partial protection (MFI $>183$ corresponding to $0.01 \mathrm{lU} / \mathrm{ml}$ ). Figure $\mathrm{S} 6$ is an extended version of this figure that also includes quantitative antibody levels. Figure created with computational notebook: https://osf.io/qrkhm . 
bioRxiv preprint doi: https://doi.org/10.1101/604181; this version posted April 19, 2019. The copyright holder for this preprint (which was

not certified by peer review) is the author/funder, who has granted bioRxiv a license to display the preprint in perpetuity. It is made available under aCC-BY 4.0 International license.

STROBE Statement - Checklist of items that should be included in reports of cross-sectional studies

Item
No Recommendation

Title and abstract $\quad 1 \quad(a)$ Indicate the study's design with a commonly used term in the title or the abstract

[The term cross-sectional is used within the title page 1 , line 1 and the abstract page 2, line 29]

(b) Provide in the abstract an informative and balanced summary of what was done and what was found [page 2, lines 28-48]

\begin{tabular}{|c|c|c|}
\hline \multicolumn{3}{|l|}{ Introduction } \\
\hline Background/rationale & 2 & $\begin{array}{l}\text { Explain the scientific background and rationale for the investigation being reported } \\
\text { [page 5, lines 96-110] }\end{array}$ \\
\hline Objectives & 3 & $\begin{array}{l}\text { State specific objectives, including any prespecified hypotheses [page 5, lines 106- } \\
\text { 110] }\end{array}$ \\
\hline \multicolumn{3}{|l|}{ Methods } \\
\hline Study design & 4 & Present key elements of study design early in the paper [page 5, line 113] \\
\hline Setting & 5 & $\begin{array}{l}\text { Describe the setting, locations, and relevant dates, including periods of recruitment, } \\
\text { exposure, follow-up, and data collection [page 5, lines 114-115] }\end{array}$ \\
\hline Participants & 6 & $\begin{array}{l}\text { (a) Give the eligibility criteria, and the sources and methods of selection of } \\
\text { participants [page 5, lines 115-117] }\end{array}$ \\
\hline Variables & 7 & $\begin{array}{l}\text { Clearly define all outcomes, exposures, predictors, potential confounders, and effect } \\
\text { modifiers. Give diagnostic criteria, if applicable [pages 8-9, lines 170-182] }\end{array}$ \\
\hline $\begin{array}{l}\text { Data sources/ } \\
\text { measurement }\end{array}$ & $8^{*}$ & $\begin{array}{l}\text { For each variable of interest, give sources of data and details of methods of } \\
\text { assessment (measurement). Describe comparability of assessment methods if there is } \\
\text { more than one group [pages 8-9, lines 170-182] }\end{array}$ \\
\hline Bias & 9 & Describe any efforts to address potential sources of bias [page 8, lines 184-217] \\
\hline Study size & 10 & Explain how the study size was arrived at [page 5, lines 114-117] \\
\hline Quantitative variables & 11 & $\begin{array}{l}\text { Explain how quantitative variables were handled in the analyses. If applicable, } \\
\text { describe which groupings were chosen and why [page 10, lines 219-228] }\end{array}$ \\
\hline Statistical methods & 12 & $\begin{array}{l}\text { (a) Describe all statistical methods, including those used to control for confounding } \\
\text { [page 10, lines 223-225] }\end{array}$ \\
\hline
\end{tabular}

(b) Describe any methods used to examine subgroups and interactions [page 10,

lines 217-219]

(c) Explain how missing data were addressed [N/A]

(d) If applicable, describe analytical methods taking account of sampling strategy

[N/A]

(e) Describe any sensitivity analyses [N/A]

\section{Results}

Participants $\quad 13^{*}$ (a) Report numbers of individuals at each stage of study-eg numbers potentially eligible, examined for eligibility, confirmed eligible, included in the study, completing follow-up, and analysed [page 10, lines 231-232; Figure S1]

(b) Give reasons for non-participation at each stage [N/A]

(c) Consider use of a flow diagram [N/A]

Descriptive data

14* (a) Give characteristics of study participants (eg demographic, clinical, social) and information on exposures and potential confounders [page 5, line 117]

(b) Indicate number of participants with missing data for each variable of interest [N/A]

Outcome data $\quad 15^{*}$ Report numbers of outcome events or summary measures [pages 11-12; Figures 
bioRxiv preprint doi: https://doi.org/10.1101/604181; this version posted April 19, 2019. The copyright holder for this preprint (which was

not certified by peer review) is the author/funder, who has granted bioRxiv a license to display the preprint in perpetuity. It is made available under aCC-BY 4.0 International license.

\section{2,3,4,5,6,S7,S8]}

\begin{tabular}{|c|c|c|}
\hline \multirow[t]{3}{*}{ Main results } & 16 & $\begin{array}{l}\text { (a) Give unadjusted estimates and, if applicable, confounder-adjusted estimates and } \\
\text { their precision (eg, } 95 \% \text { confidence interval). Make clear which confounders were } \\
\text { adjusted for and why they were included [N/A] }\end{array}$ \\
\hline & & (b) Report category boundaries when continuous variables were categorized [N/A] \\
\hline & & $\begin{array}{l}\text { (c) If relevant, consider translating estimates of relative risk into absolute risk for a } \\
\text { meaningful time period }[\mathbf{N} / \mathbf{A}]\end{array}$ \\
\hline Other analyses & 17 & $\begin{array}{l}\text { Report other analyses done- - eg analyses of subgroups and interactions, and } \\
\text { sensitivity analyses [pages 11-12; Figures } \mathbf{2 , 3 , 4 , 5 , 6 , S 7 , S 8 ]}\end{array}$ \\
\hline \multicolumn{3}{|l|}{ Discussion } \\
\hline Key results & 18 & $\begin{array}{l}\text { Summarise key results with reference to study objectives [pages 12-16, lines 281- } \\
\text { 377] }\end{array}$ \\
\hline Limitations & 19 & $\begin{array}{l}\text { Discuss limitations of the study, taking into account sources of potential bias or } \\
\text { imprecision. Discuss both direction and magnitude of any potential bias [pages 16- } \\
\text { 17, lines 378-396] }\end{array}$ \\
\hline Interpretation & 20 & $\begin{array}{l}\text { Give a cautious overall interpretation of results considering objectives, limitations, } \\
\text { multiplicity of analyses, results from similar studies, and other relevant evidence } \\
\text { [pages } 17 \text {, lines } 397-408 \text { ] }\end{array}$ \\
\hline Generalisability & 21 & $\begin{array}{l}\text { Discuss the generalisability (external validity) of the study results [pages } \mathbf{1 3 - 1 5} \text {, } \\
\text { lines 290-296, 313-321, 342-348] }\end{array}$ \\
\hline \multicolumn{3}{|c|}{ Other information } \\
\hline Funding & 22 & $\begin{array}{l}\text { Give the source of funding and the role of the funders for the present study and, if } \\
\text { applicable, for the original study on which the present article is based [Within } \\
\text { acknowledgements] }\end{array}$ \\
\hline
\end{tabular}

*Give information separately for exposed and unexposed groups.

Note: An Explanation and Elaboration article discusses each checklist item and gives methodological background and published examples of transparent reporting. The STROBE checklist is best used in conjunction with this article (freely available on the Web sites of PLoS Medicine at http://www.plosmedicine.org/, Annals of Internal Medicine at http://www.annals.org/, and Epidemiology at http://www.epidem.com/). Information on the STROBE Initiative is available at www.strobe-statement.org. 
Table S1. Seropositivity cutoff values estimated for each antigen. The cutoff values for vaccine preventable diseases (tetanus, diphtheria, and measles) are based on seroprotection levels derived from a standard curve using international reference. The cutoff values are plotted in Figure 1 of the manuscript.

\begin{tabular}{|c|c|c|}
\hline Antigen & Method & $\begin{array}{l}\text { Cutoff } \\
\text { (MFI-bg) }\end{array}$ \\
\hline Tetanus toxoid & Standard curve, Pos $>0.01 \mathrm{IU} / \mathrm{ml}$ & 118 \\
\hline Diphtheria toxoid & Standard curve, Pos $>0.1 \mathrm{IU} / \mathrm{ml}$ & 4393 \\
\hline Measles MV-N & Standard curve, Pos $>9.5 \mathrm{mlU} / \mathrm{ml}$ & 178 \\
\hline Plasmodium falciparum CSP & Gaussian mixture model $^{a}$ & 367 \\
\hline Plasmodium falciparum MSP-1 19 & USA unexp. pop., mean + 3SD of log values & 256 \\
\hline Plasmodium falciparum MSP-1 19 & Gaussian mixture model $^{a}$ & 416 \\
\hline Plasmodium malariae MSP-1 $1_{19}$ & USA unexp. pop., mean + 3SD of log values & 403 \\
\hline Plasmodium malariae MSP-1 19 & Gaussian mixture model $^{a}$ & 196 \\
\hline Lymphatic filariasis Wb123 & USA unexp. pop., mean + 3SD & 342 \\
\hline Lymphatic filariasis Wb123 & Gaussian mixture model $^{\mathrm{a}}$ & 366 \\
\hline Lymphatic filariasis Bm14 & USA unexp. pop., mean + 3SD & 444 \\
\hline Lymphatic filariasis Bm14 & Gaussian mixture model $^{\text {a }}$ & 214 \\
\hline Lymphatic filariasis Bm33 & USA unexp. pop., mean + 3SD & 369 \\
\hline Lymphatic filariasis Bm33 & Gaussian mixture model $^{\mathrm{a}}$ & 791 \\
\hline Schistosoma mansoni SEA & ROC analysis with pos/neg samples & 965 \\
\hline Schistosoma mansoni SEA & Gaussian mixture model $^{a}$ & 476 \\
\hline Schistosoma mansoni Sm 25 & ROC analysis with pos/neg samples & 38 \\
\hline Schistosoma mansoni Sm25 & Gaussian mixture model $^{a}$ & 32 \\
\hline Strongyloides stercoralis NIE & USA unexp. pop., mean + 3SD & 628 \\
\hline Strongyloides stercoralis NIE & Gaussian mixture model $^{\text {a }}$ & 645 \\
\hline Ascaris AsHb & ROC analysis with pos/neg samples & 386 \\
\hline Ascaris AsHb & Gaussian mixture model $^{a}$ & 780 \\
\hline
\end{tabular}

${ }^{a}$ Model fit using the mixtools package in $\mathrm{R}$ on the original scale of the antibody measurement, and assuming a mixture of 2 components. The mean of the lower component + 3SD was used to determine cutoff values. The script used to run the mixture model analyses is here: https://osf.io/dm324, and the log output from the analysis (estimates copied/pasted to table) is here: https://osf.io/ms39q 

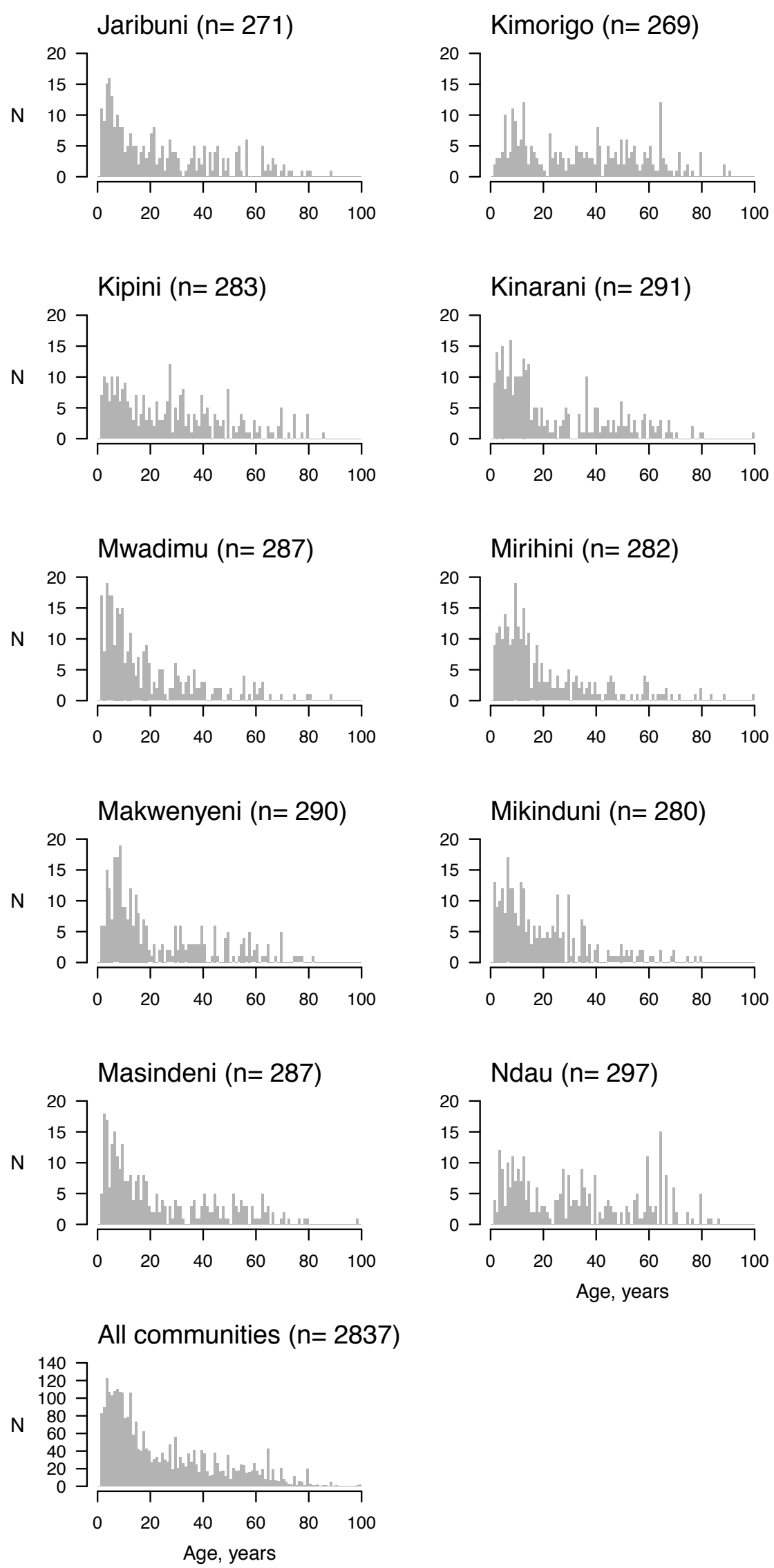

Fig. S1: Community level sample size and age distribution. Figure created with computational notebook: https://osf.io/7jxmn. 

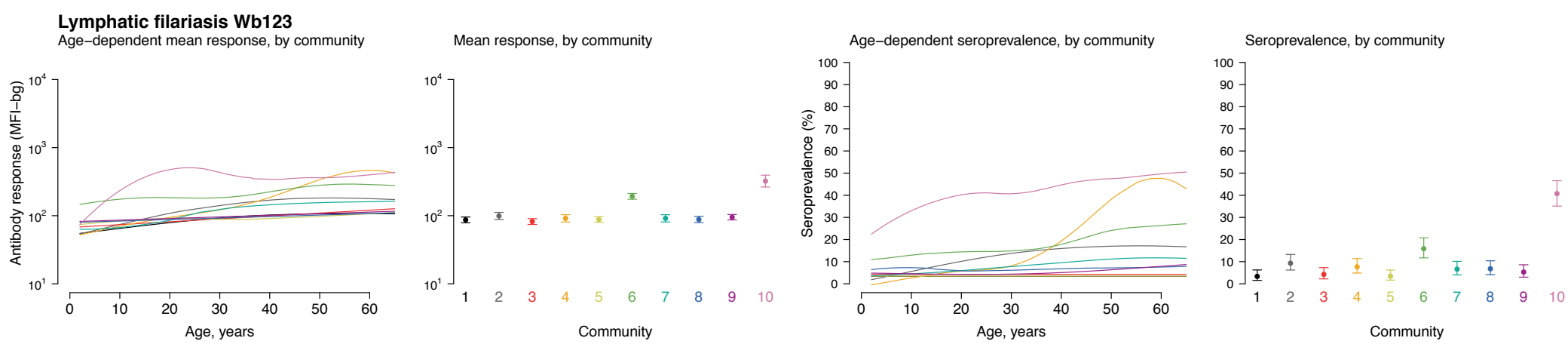

Lymphatic filariasis Bm14
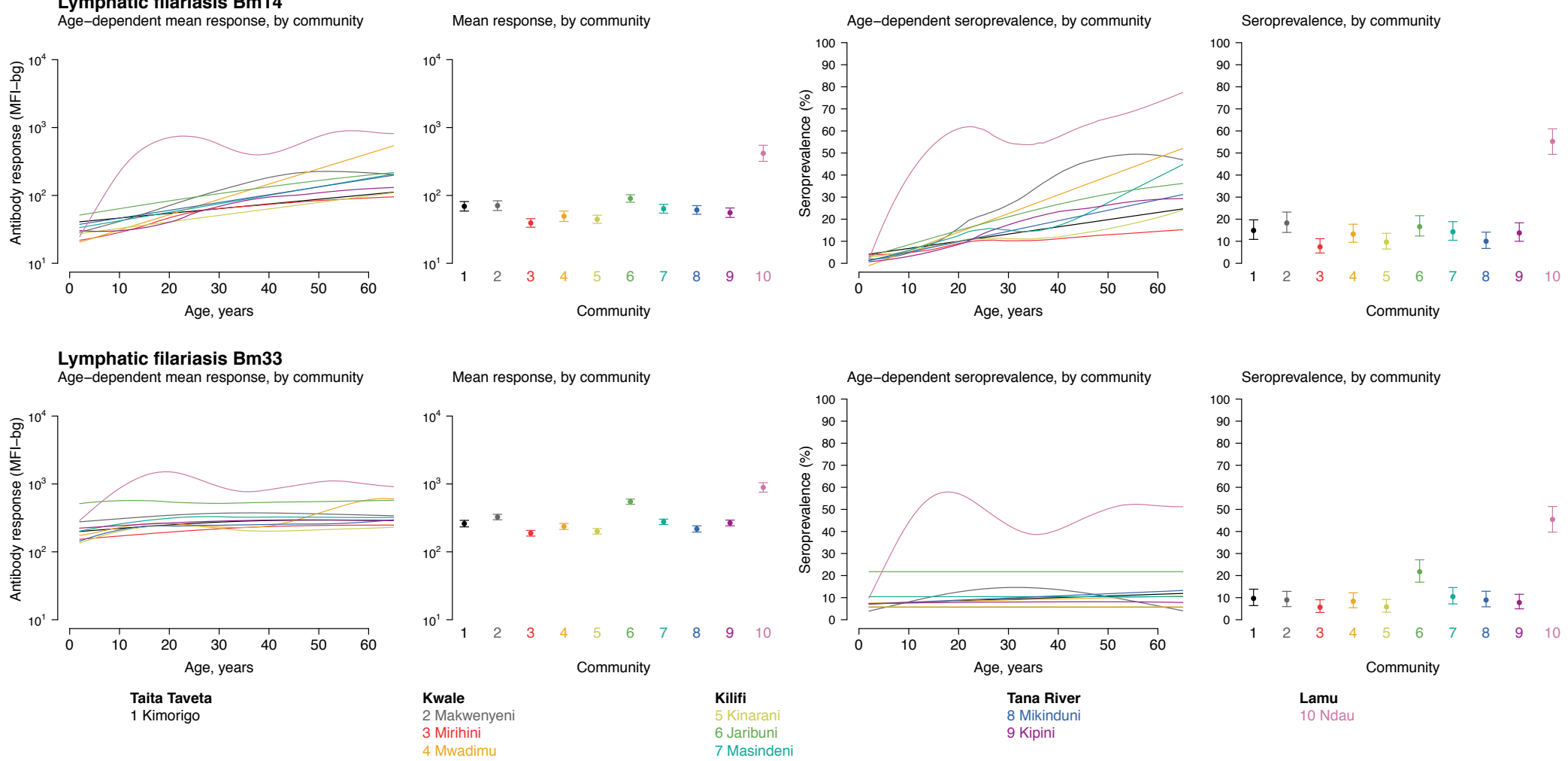

Fig. S2 : Lymphatic filariasis antibody age-dependent mean response and seroprevalence, stratified by community in Kenya?s coastal region, 2015. Community-level mean antibody response and seroprevalence are age-adjusted and error bars represent $95 \%$ confidence intervals. Antibody response measured in median fluorescence units minus background (MFI-bg) on a BioRad Bio-Plex platform. Figure created with computational notebook: https://osf.io/c79rw . 

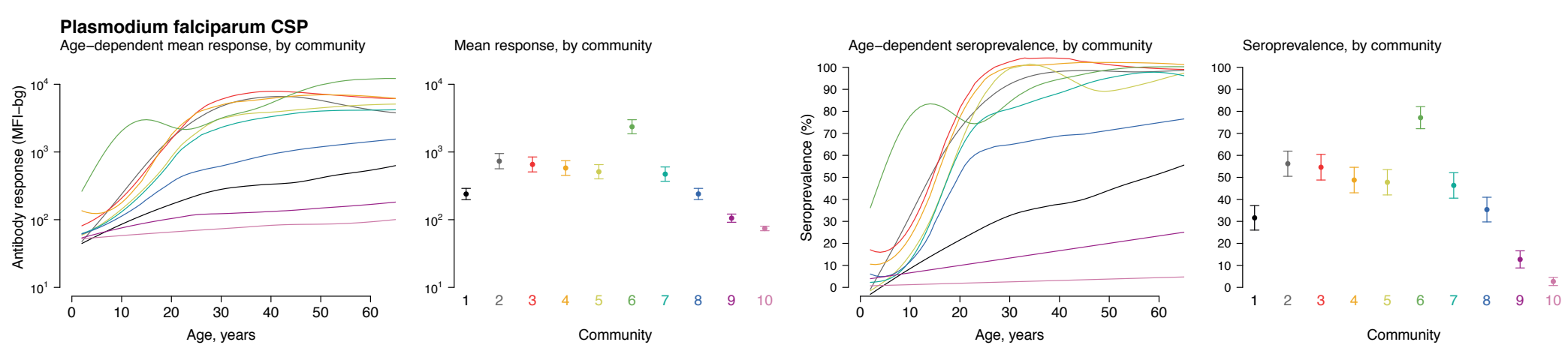

Plasmodium falciparum MSP-1

Age-dependent mean response, by community

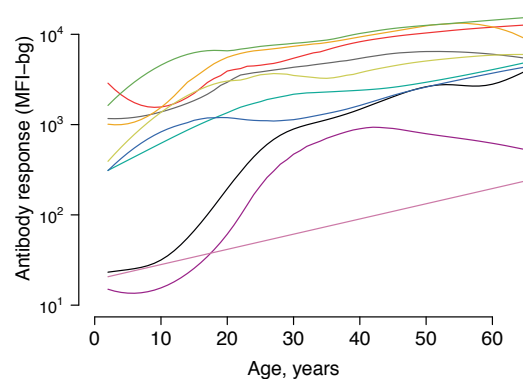

Mean response, by community
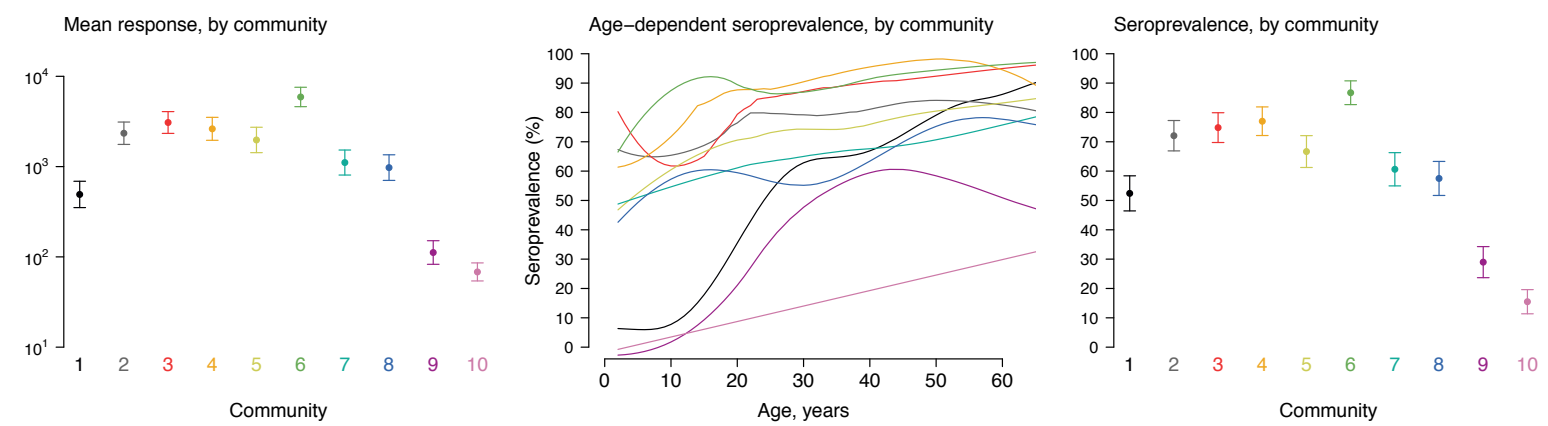

Plasmodium malariae MSP-1

Age-dependent mean response, by community
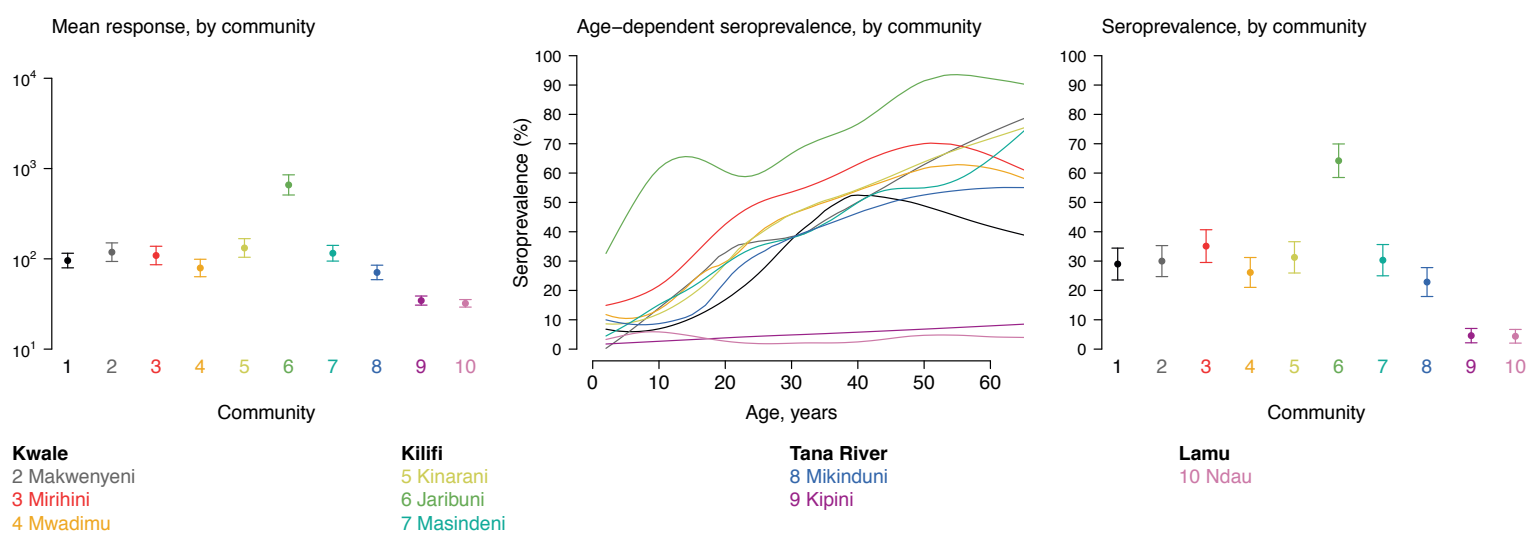

Fig. S3 : S3 Figure: Malarial antibody age-dependent mean response and seroprevalence, stratified by community in Kenya?s coastal region, 2015. Community-level mean antibody response and seroprevalence are age-adjusted and error bars represent $95 \%$ confidence intervals. Antibody response measured in median fluorescence units minus background (MFI-bg) on a BioRad Bio-Plex platform. Figure created with computational notebook: https://osf.io/nhrc2. 
S. mansoni SEA

Age-dependent mean response, by community

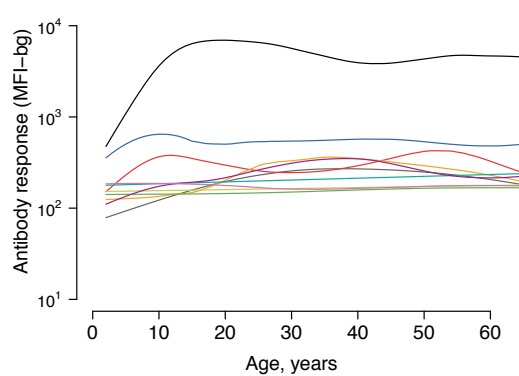

S. mansoni Sm25

Age-dependent mean response, by community

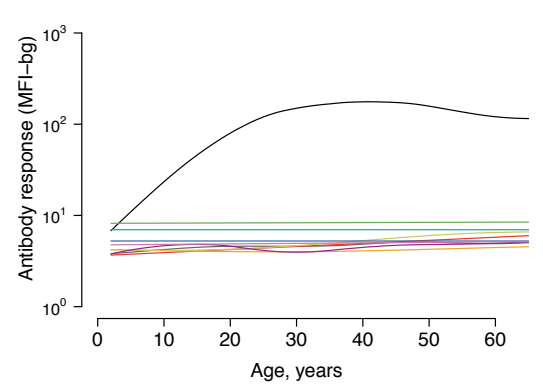

Taita Taveta

Taita Taveta
1 Kimorigo
Mean response, by community

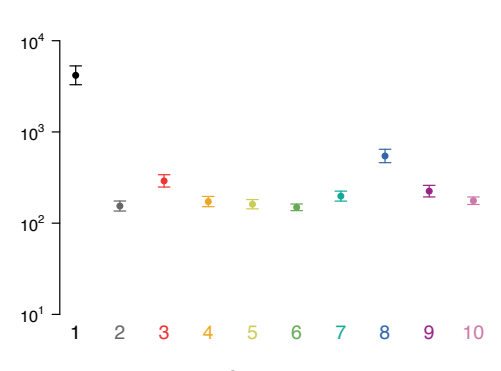

Community

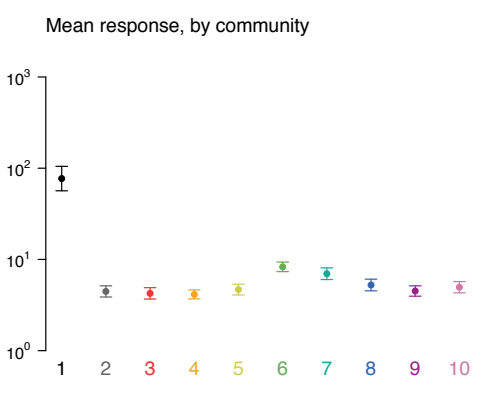

Community

\section{Kwale}

2 Makwenyen

3 Mirihini

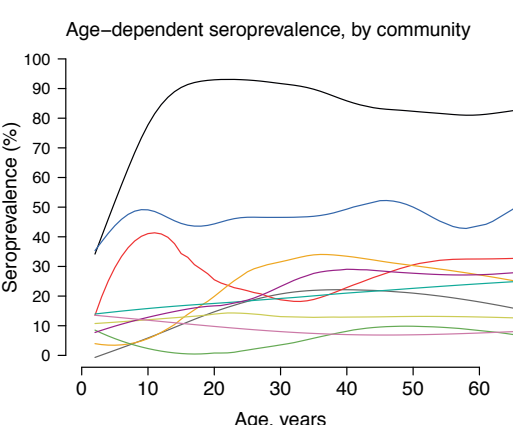

Age, years

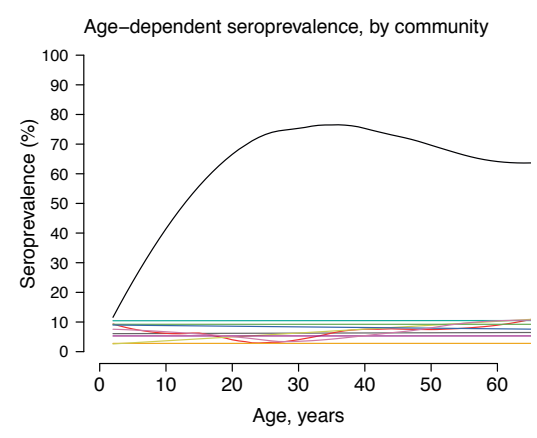

Age, years

Tana River
8 Mikindun
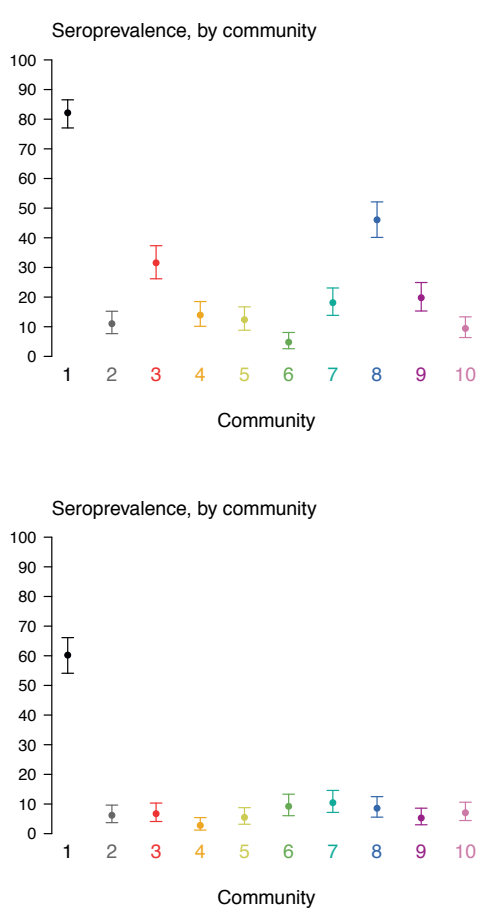

Lamu

Fig. S4 : Schistosomiasis antibody age-dependent mean response and seroprevalence, stratified by community in Kenya?s coastal region, 2015. Community-level mean antibody response and seroprevalence are age-adjusted and error bars represent $95 \%$ confidence intervals. Antibody response measured in median fluorescence units minus background (MFI-bg) on a BioRad Bio-Plex platform. Figure created with computational notebook: https://osf.io/z8v4n. 

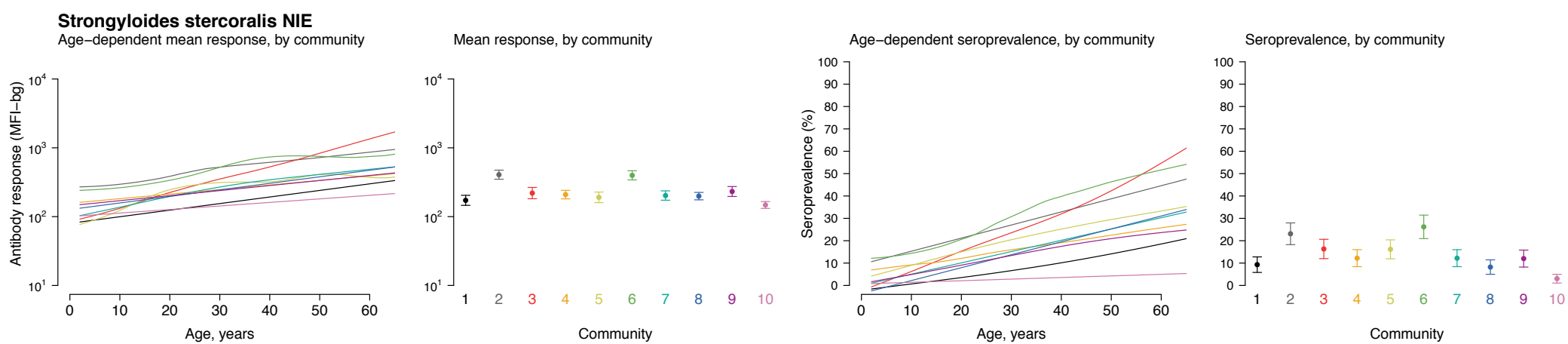

\section{Ascaris AsHb}

Age-dependent mean response, by community

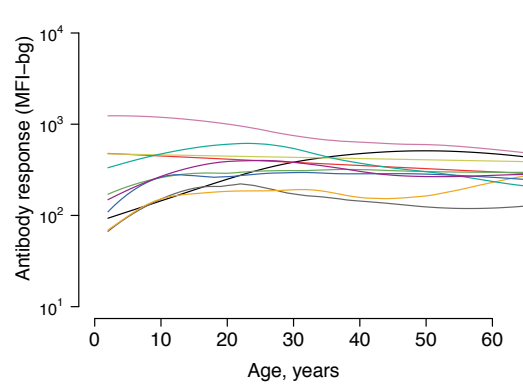

Mean response, by community
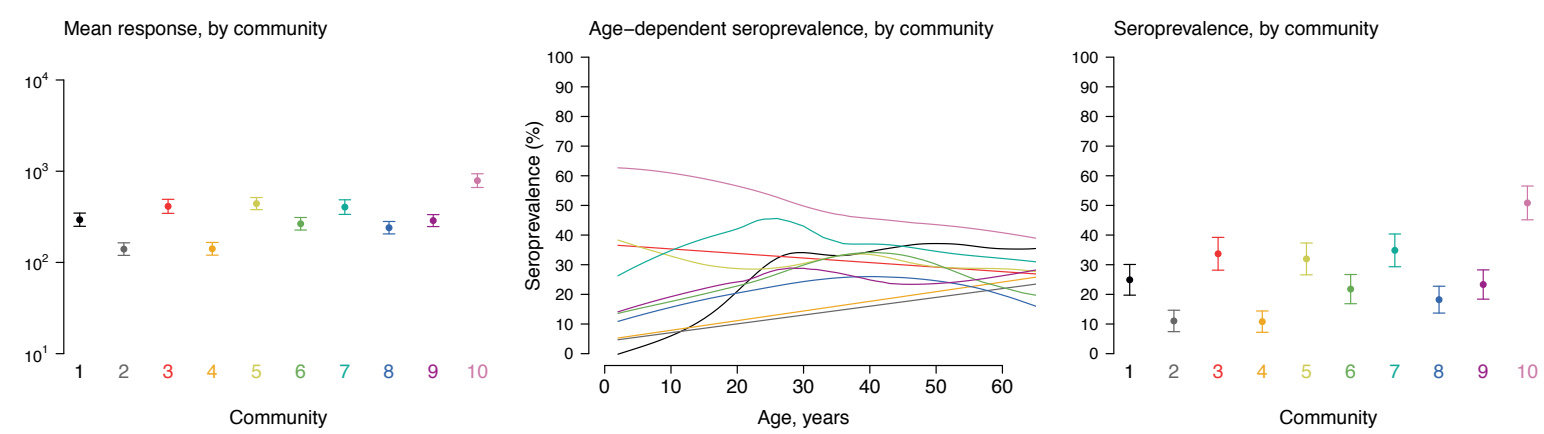

Taita Taveta
1 Kimorigo

Community

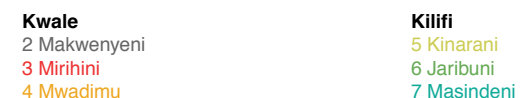

Tana River
8 Mikinduni

Lamu

Fig. S5 : Age-dependent mean response and seroprevalence antibodies to S. stercoralis and A. lumbricoides, stratified by community in Kenya?s coastal region, 2015. Community-level mean antibody response and seroprevalence are age-adjusted and error bars represent $95 \%$ confidence intervals. Antibody response measured in median fluorescence units minus background (MFI-bg) on a BioRad Bio-Plex platform. Figure created with computational notebook: https://osf.io/spnvx. 

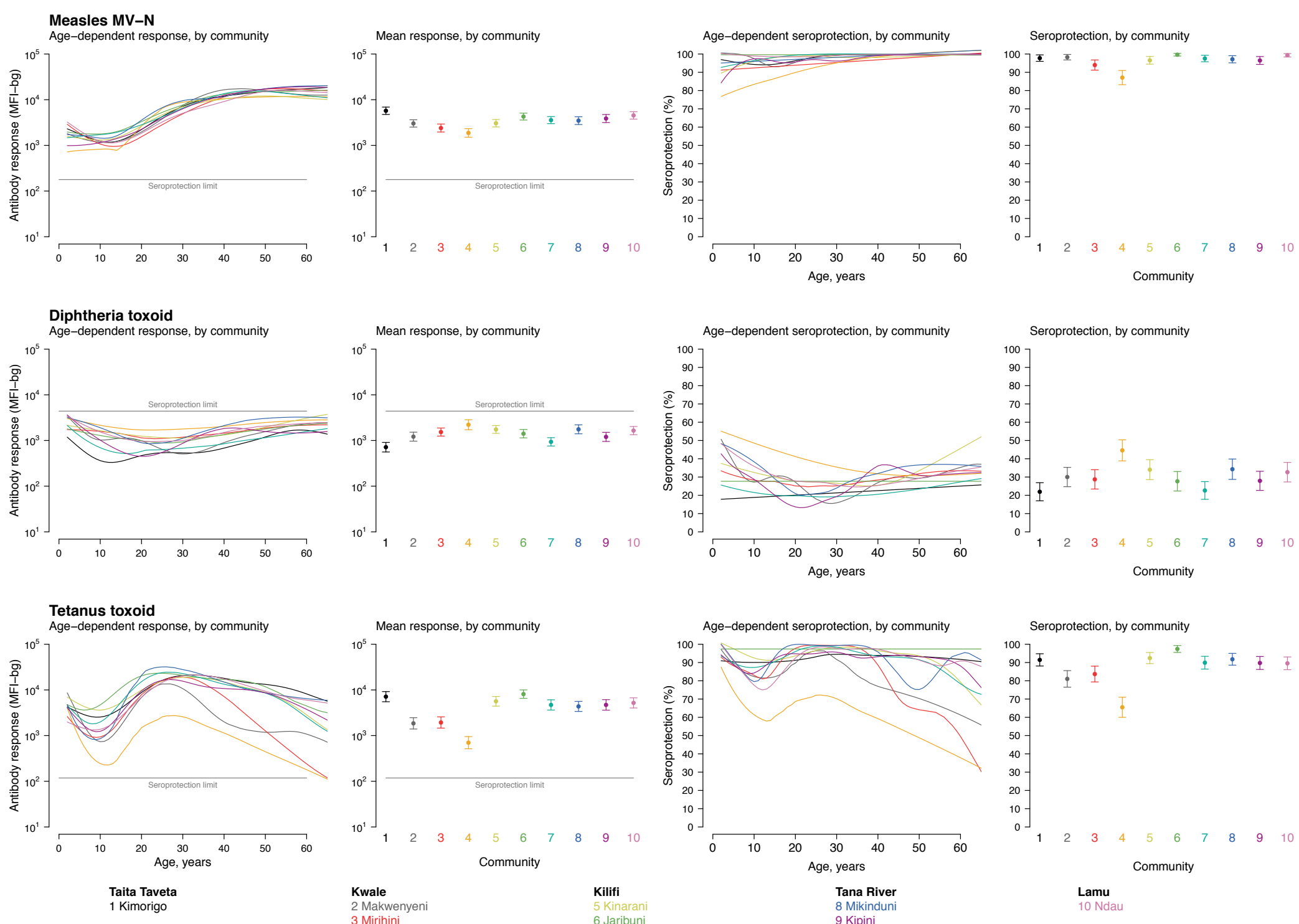

Fig. S6 : Age-dependent mean response and seroprotection for measles, diphtheria, and tetanus stratified by community in Kenya?s coastal region, 2015. Community-level mean antibody response and seroprotection are age-adjusted and error bars represent $95 \%$ confidence intervals. Antibody response measured in median fluorescence units minus background (MFI-bg) on a BioRad Bio-Plex platform. Figure created with computational notebook: https://osf.io/uy5bf. 


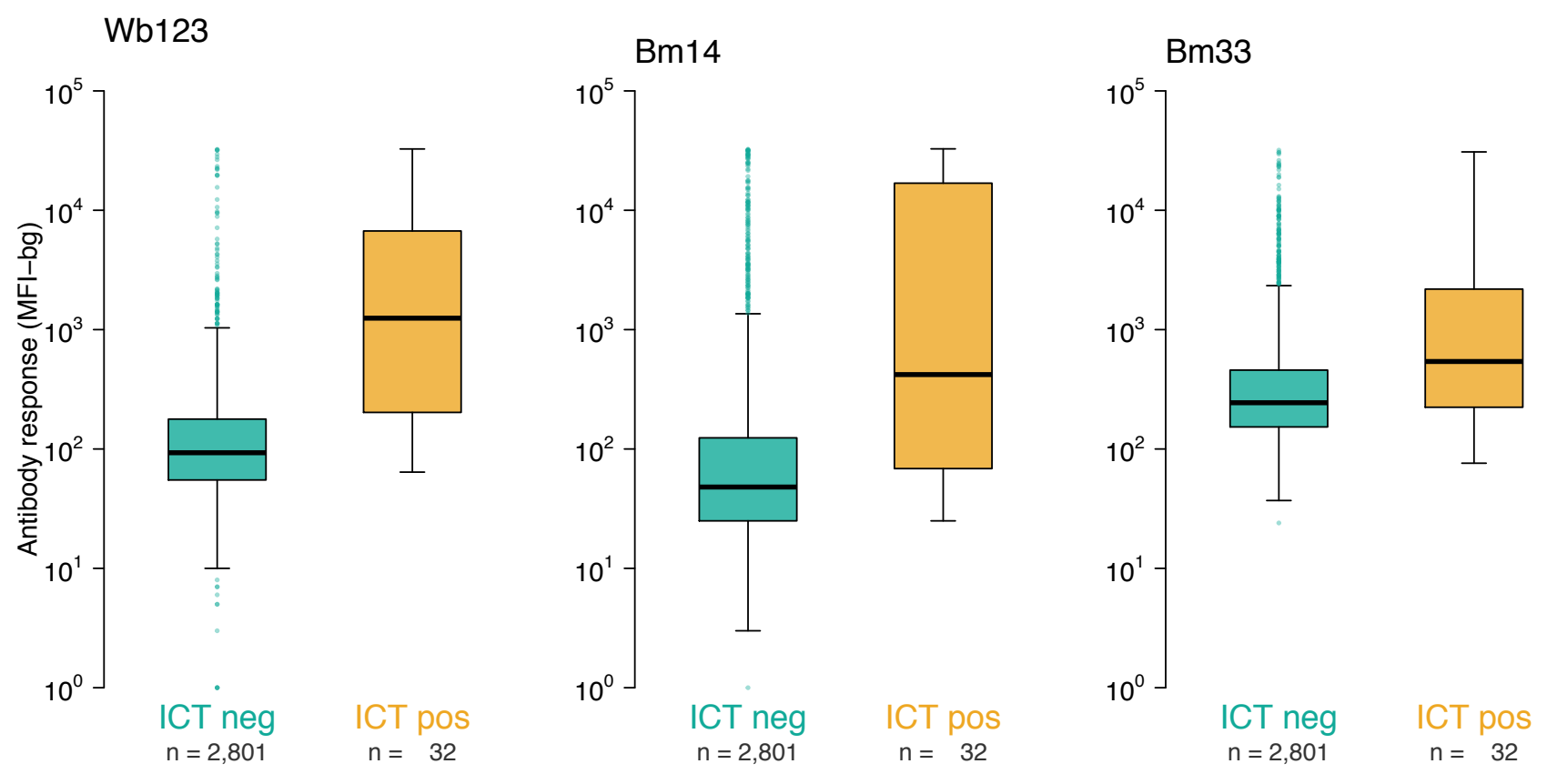

Fig. S7 : Distribution of three lymphatic filariasis antibodies, stratified by rapid antigen immunochromatographic card test (ICT) results. Boxes mark the median and interquartile range of the distributions. Antibody response measured in median fluorescence units minus background (MFI-bg) on a BioRad Bio-Plex platform. Mann-Whitney U-test $P<0: 0001$ for differences in antibody responses between ICT negative and positive individuals. Figure created with computational notebook: https://osf.io/k9tms. 

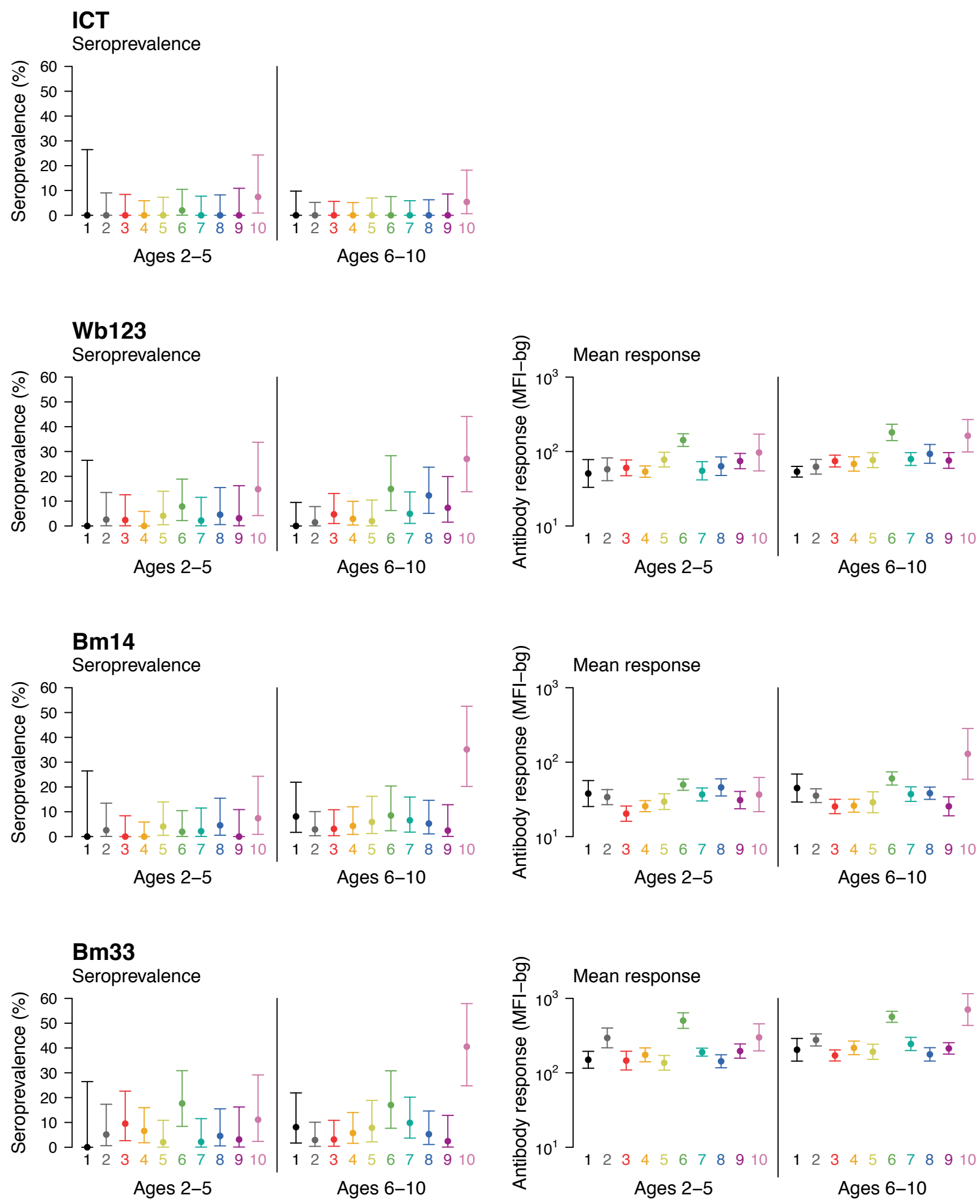

$\begin{array}{lllll}\text { Taita Taveta } & \text { Kwale } & \text { Kilifi } & \text { Tana River } & \text { Lamu } \\ \text { 1 Kimorigo } & \text { 2 Makwenyeni } & 5 \text { Kinarani } & 8 \text { Mikinduni } & 10 \text { Ndau } \\ & \text { 3 Mirihini } & 6 \text { Jaribuni } & 9 \text { Kipini } & \\ & 4 \text { Mwadimu } & 7 \text { Masindeni } & \end{array}$

Fig. S8 : Community level estimates of lymphatic filariasis seroprevalence and geometric mean antibody levels among children ages 2-5 and 6-10 years old. Child blood samples were tested the immunochromatographic card test (ICT) and three antigens (Wb123, Bm14, Bm33) measured in median fluorescence units minus background (MFI-bg) on a multiplex BioRad Bio-Plex platform. The mean number of specimens tested per community within each age stratum was 47 (median $=47$; interquartile range $=39,58$; range $=12,70$ ). Figure created with computational notebook: https://osf.io/xh9yt. 